\title{
Discovery of Messinian Canyons and new seismic stratigraphic model, Offshore Provence (SE France): implications for the hydrographic network reconstruction
}

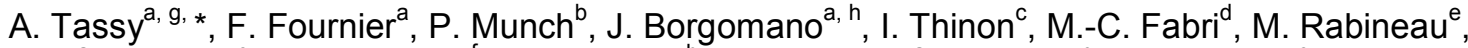 \\ B. Arfib ${ }^{a}$, J. Begot ${ }^{e}$, M.-O. Beslier ${ }^{f}, J^{-}$-J. Cornée ${ }^{b}$, A. Fournillon ${ }^{a}$, C. Gorini ${ }^{g}$, P. Guennoc ${ }^{c}$, P. Léonide ${ }^{a}$, \\ J. Oudet ${ }^{a}$, F. Paquet ${ }^{c}$, F. Sage, R. Toullec ${ }^{a}$
}

${ }^{a}$ CEREGE, Aix-Marseille University, 3 Place Victor Hugo, Marseille, France

b UMR5243-Géosciences Montpellier, Université Montpellier 2, cc060, Montpellier, France

${ }^{c}$ DGR/GBS BRGM 3 av Claude Guillemein, BP 36009, Orléans, France

d Ifremer Méditerranée Laboratoire Environnement LER/PAC Z.P. de Brégaillon La Seyne/Mer, France

e IUEM, Plouzane, France

${ }^{f}$ UMR 73-29-GéoAzur, Villefranche sur Mer, France

${ }^{g}$ ISTeP, Université Pierre et Marie Curie / CNRS Paris, France

h TOTAL CST JF, Pau, France

*: Corresponding author : A. Tassy

\begin{abstract}
:
The interpretation of high-resolution 2D marine seismic profiles together with the analysis of sea-bottom cores allowed a stratigraphic and structural framework of the Provence continental shelf to be proposed. The integration of onshore and offshore stratigraphy, structure and geomorphology provided new insights into Messinian paleotopography and paleohydrography. A geological map of the offshore Provence continental shelf, isobath map of the base Plio-Quaternary surface are presented for the first time in this area. The base Plio-Quaternary surface is a polyphased unconformity that is composed of deep canyons developed by fluvial erosion during the Messinian event, and wave-cut surfaces formed during post-Messinian transgressions. The study evidenced a deep, E-W-trending canyon (Bandol canyon) connected to the head of the Cassidaigne canyon, and filled with up to $600 \mathrm{~m}$-thick Plio-Quaternary deposits. The development of canyons on the Provence margin during the Messinian event was dominantly controlled by the lithology and structure of pre-Messinian formations. A map of the Messinian paleo-drainage network is proposed to explain the presence of deep canyons in the Eastern area and the lack of incision in the Western area. An underground karst drainage scheme is proposed, linked with the current submarine Port-Miou spring.
\end{abstract}

\section{Highlights}

2D seismic profiles and sea-bottom cores are performed on the Provence margin. Interpretation is based on the integration with the onshore stratigraphy. Geological map of the continental shelf is provided for the first time in the area. 3D land-sea surface of Messinian paleotopography and paleohydrography is provided. E-W infilled Messinian canyon has been discovered, connected to Cassidaigne canyon.

Keywords : Western Mediterranean ; Provence continental shelf ; Base Plio-Quaternary Surface ; Submarine canyon ; Karst ; Offshore seismic data ; Shallow coring ; Geological mapping 


\section{Introduction}

Outcrops in Provence have been exhaustively studied, however few studies focused on the marine geology and the possible offshore continuity of onshore structures. It is a complex geological domain situated between the Alpine arc and the continental margin of the LiguroProvençal back-arc basin which was also influenced by the high amplitude Neogene eustatic changes, especially during the Messinian Salinity Crisis (MSC). The salinity crisis in the Mediterranean basin during the Messinian is considered as one of the most spectacular events in marine environments since the beginning of the Neogene. During the Messinian, the reduced inflow of Atlantic Ocean water through the Betic and Rifian corridors combined to a high evaporation rate induced a dramatic Mediterranean base level drop of at least 1500m (Ryan and Cita 1978; Benson et al. 1991; Krijgsman et al. 1999; Jolivet et al. 2008). In spite of the common acceptance of a deep-dessicated Mediterranean basin, various aspects of the Messinian eustatic event are still in debate, such as: 1) the basinward and landward extension of the Messinian Erosional Surface (MES), interpreted as a subaerial erosion (Clauzon 1973 ; Ryan 1976 ; Ryan et Cita 1978 ; Rizzini et al. 1978; Barber 1981; Clauzon 1982 ; Gorini et al. 1993 ; Guennoc et al. 2000; tofi 2002 ; Lofi et al. 2003, 2005 ; Gorini et al. 2005, Lofi and Berné 2008, Lofi et al. 2011, Bache et al. 2009), 2) the re-flooding scenarii at the end of the crisis and the sedimentary architecture of Pliocene canyon infills (Denizot 1952; Chumakov 1973; Clauzon 1973 et 1982; Barber 1981, Hsü et al. 1973 ; Clauzon and

Cravatte 1985 ; Blanc 2002 ; Lofi et al., 2003; Loget et al. 2005; Bache et al. 2012), and 3) the structuration of deep karst systems related to the lowering of the water table (Audra et al. 2004, Mocochain et al. 2006a,b,c, 2009).

In South of France, most of the studies related to the markers of the MSC and PlioQuaternary deposits focused on the southwestern and central part of the Gulf of Lion margin (e.g. Lofi et al. 2003; Bache et al. 2009), the deep-provençal margin (Obone-Zue-Obame et al. 2011) and the Ligurian margin (Sage et al. 2011). The published maps of the MES on the Gulf of Lion margin (Gennesseaux and Lefebvre 1980; Guennoc et al. 2000) evidence a 
buried Messinian drainage network comprising two main valley systems, the Rhône valley system to the northeast, and the Languedoc-Roussillon valley system to the southwest.

Between Marseille and Toulon, the MES hasn't been mapped and the impact of the Messinian eustatic event on the coastal hydrologic systems was never investigated in this area. However, submersible dives in the Stoechades and St-Tropez canyons (Groupe Estocade, 1978 ; Bellaiche et al., 1978; Bellaiche et al., 1979; Bellaiche et al., 1991; Roure et al., 1978) outlined the occurrence of Messinian subaerial erosion on the offshore Provence, East of Toulon. The area between Marseille and Toulon is characterized by the evidence of deep canyons incising a narrow shelf break, the Cassidaigne and Planier canyons which do not extend to the present-day coastline. Onland, the area is characterized by deep phreatic coastal karst and minor coastal rivers draining Marseille and Beausset basins. The Cassidaigne canyon is the largest one and consists of an up to $1700 \mathrm{~m}$ deep and $20 \mathrm{~km}$ long incision, located $8 \mathrm{~km}$ south from the coast. It is oriented NNE-SSW in its upper part and direction move toward NW-SE in its lower part. Its abrupt edges are asymmetric and mainly controlled by the nature of the rocks subcropping on the margin during its formation.

To improve our knowledge on this key domain within the context of the characterization of coastal karst system, it is critical to integrate data from onshore geology and offshore seismics. On the basis of the integration of a wide marine seismic database, sea-bottom cores and onland field studies, the present work aims at: 1) Providing a detailed map of the MES on the offshore Provence continental shelf, 2) Assessing the role of the pre-Messinian structural framework on the Messinian canyon development from a new geological map of the offshore Provence continental shelf, 3) Reconstructing the Messinian and Pliocene drainage network, 4) Estimating the role of the Messinian karstification on the present-day marine physiography.

\section{Geological setting}

The study area is located in South-East of France between the Gulf of Lion margin and the Ligurian margin. It comprises the whole continental shelf offshore Provence and the coastal massifs (Nerthe, Etoile, Calanques, Sicié) and basins (Marseille, Le Beausset) from La Couronne to Sicié Cape (Fig. 1). The offshore Provence continental shelf can be divided into 
three main structural domains (Fig. 1). The Western Area, south of the Nerthe massif, represents the seaward extension of the Marseille Oligocene basin. The Central Area, located between the Planier island and the Cassidaigne canyon, is a submarine plateau made of Mesozoic rocks resulting from marine abrasion during Quaternary transgressions and karstified during sea level lowstands (Froget 1974; Collina-Girard 1999). The Eastern area, extending from the Cassidaigne canyon to the Sicié, is the seaward extension of the Bandol and Cap Sicié thrust-belts (Ducrot 1967; Froget 1974).

The Gulf of Lion and Ligurian margins are parts of the northern margins of the LiguroProvencal basin, which is considered as a back-arc basin opened by counter-clockwise rotation of Corsica-Sardinia micro-plate during the Miocene (Carminati et al. 1998a and 1998b; Gueguen et al. 1998; Séranne 1999; Gorini 1993; Jolivet et al. 2006; Gattacceca et al. 2007). In contrast to the Gulf of Lion margin, the Ligurian margin was strongly influenced by the alpine tectonics, ante-, syn-, and post-Liguro-Provencal rifting (Bigot-Cormier et al. 2004, Sage et al. 2011). Few structural and sedimentological studies have focused on this transitional zone and published seismic and core data are scarce (Leenhardt et al. 1969; Ducrot 1967; Froget 1967, 1972, 1974), in contrast to the Gulf of Lion margin (e.g. Lefebvre 1980; Gorini 1993; Guennoc et al. 1994, 2000, Séranne 1999; Lofi et al. 2003, 2005; Lofi and Berné 2008; Bache et al. 2009, 2010) and the Ligurian margin (e.g. Rollet 1999; Sage et al. 2011; and references above). The structure of the Lower Provence margin (Fig. 2), bounded to the North by the Nerthe and Etoile thrusts, and to the East by the Maures Hercynian basement, is considered to be mainly controlled by the i) Pyrenean compressional phase that would have been responsible for E-W north-verging thrusts on the area (Nerthe, Etoile, Sainte Baume, Bandol slices; Villeger and Andrieux, 1987; Séranne, 1999), and ii) the Oligocene to Aquitanian rifting phase (Debrand-Passard and Courbouleix 1984) while resulting in the formation of horsts and grabens structures (Gorini 1993, Séranne 1999, Guennoc et al. 2000) such as the Marseille basin. On the continental shelf, syn-rift deposits fill the graben and are unconformably covered by two major post-rift sedimentary units (Gorini et al. 1993): the Miocene unit fGorini 1993; Lofi 2002; Bache al. 2003; Oudet et al. 20102) and the PlioQuaternary unit (Froget 1967, 1972, 1974; Rabineau al. 2005). These units are separated by the MES (Cita and Ryan 1978; Guennoc et al. 2000; Lofi et al. 2011b). In the Rhône and Durance valleys, the ASC drawn is recorded by a major erosionalsurface MES is sealed 
by marine Pliocene deposits (Clauzon 1973) while in the onshore Lower Provence it is evidenced by deep karst features (Audra et al. 2004).

Onshore coastal massifs are dominantly made of carbonate rocks displaying karstic features such as karst valleys, poljes, and caves. The surface hydrographic network consists of five coastal rivers: Huveaune river which flows from the Sainte Baume massif to the sea through the Oligocene Marseille basin, Grand Vallat river which flows across the Cretaceous Beausset basin, Las and Gapeau river draining the Eastern flank of the Beausset basin, and Reppe river to the South-East. These last two rivers are connected to the sea through incised Mesozoic limestones (Fig. 1). Drainage network is also characterized by an active karst system that is developed in the fractured Urgonian limestone and that displays three major outlets, the submarine springs of Port-Miou and Bestouan at the West, and the Dardennes spring at the East (Fig. 1). Offshore, the continental shelf morphology is relatively flat from the coast to the shelf-break which is incised by Cassidaigne and Planier submarine canyons (Fig.1). The Cassidaigne canyon is the largest one and consists of an up to $1700 \mathrm{~m}$ deep and $20 \mathrm{~km}$ long incision, located $8 \mathrm{~km}$ south from the coast. It is oriented NNE-SSW in its upper part and direction move toward NW-SE in its lower part (Fig. 1 and 17). The morphology of the canyon (Fig. 17; ESROV 2010 survey - Ifremer) can be split in three parts: i) The head of the canyon results from the intersection of four main erosive valleys showing singular axis directions; ii) in the intermediate domain the incision is deeper and reaches $1200 \mathrm{~m}$; iii) then the canyon incision reaches $1700 \mathrm{~m}$ depth and is pinched against an E-W bathymetric high before opening into the basin $7 \mathrm{~km}$ seawards, to the SE.

The study site interest consists in its location from land to sea, in a Mediterranean geodynamic context affected by the MSC, and with complex geological structures that impact on the drainage network location.

\section{Data and methods}

The dataset used in this study includes marine seismic reflection 2D profiles, rock samples extracted from seabed and coastal outcrop data. Marine seismic data were acquired during 4 surveys using the R/V TETHYS II ship (Fig. 2): MAST5913 (2007-2009), MARSOLIG (2008), CASSEIS (2009) and CASSEIS II (2011). 
The seismic profiles covers more than $1800 \mathrm{~km}^{2}$ with a total survey length of $2740 \mathrm{~km}$, a mean profile spacing of $1 \mathrm{~km}$. Seismic profiles consists of 255 high resolution (HR) and very high resolution (VHR) sections with a recording length ranging from $0.2 \mathrm{~s}$ to $2 \mathrm{~s}$ Two-WayTravel-Time (TWTT). High resolution and very high resolution profiles were acquired respectively using three seismic sources, Sercel miniGI air-gun and SIG sparker electrodes 1000J and SIG sparker electrodes 50J. For MARSOLIG survey, 1000J sparker profiles were performed using a multichannel streamer (6), and 50J sparker profiles were performed using a single channel streamer. For CASSEIS survey, a multichannel streamer (12 traces) was used for air-gun seismic acquisition while sparker profiles were performed using a single channel streamer (power supply: 50J).

In addition, older industrial and academic seismic surveys were integrated in this study (e.g. Gorini 1993; Dos Reis 2001; Lofi et al.,2003; Oudet et al., 2010): GL80 (TOTAL), RM84 (TOTAL), MARION (IFREMER), Me-Sea (IFREMER) and Carry (EOSYS). Paper seismic profiles from Leenhardt (1969) were used for geological interpretations but not integrated in the digital dataset.

The present study integrates seabed rock sample descriptions published by Froget (1967, 1972, and 1974) and newly acquired samples collected with the CNEXO-VILLE ROCK CORER (BRGM) during the CASSEIS (2009) cruise (Tab. 1).

The interpretation of the digital seismic lines was realized with the Kingdom Suite ${ }^{\mathrm{SMT}}$ software. The seismic interpretation is based on (1) the identification of major seismic horizons over the surveyed area and imaged by a maximum of cross-cutting lines and (2) the definition of seismic units that are bounded by extensively correlable seismic reflectors or seismic termination envelopes and that are characterized by a given seismic facies. The lack of offshore wells in the studied area did not allow direct lithologic and chronostratigraphic calibration of the seismic strata. The vicinity of coastal outcrops allowed stratigraphical and structural calibration of seismic data in complement to seabed rock sample analysis. The chrono-stratigraphic interpretation of the seismic unconformities and units are based on 1) the interpretation of seismic facies in terms of lithology and small-scale (meter to decameter-scale) heterogeneity distribution, 2) the comparison between the seismic stratigraphic patterns evidenced from profiles offshore and the regional stratigraphic architecture onshore and 3 ) the dating of seabed rock samples located on seismic profiles. Ages for seabed rock samples were obtained using benthic foraminiferal biostratigraphy or, 
when relevant microfossils were lacking, by lithologic and faciologic analogies with onshore regional outcrops.

The DTMs (in s TWTT), presented in this paper, were built from the seismic interpretations using the Kingdom Suite ${ }^{\text {SMT }}$ software. These gridded data have been converted in depth using the velocity law of Lofi et al. (2003) for the Plio-Quaternary cover of the Gulf of Lion area and validated by borehole data:

$$
D=-0.0002 \times T^{3}+0.6238 \times T^{2}+788.95 \times T
$$

where $D$ is the calculated depth $(m)$ and T the travel time (msec TWTT) below seabed from the seismic profile. We used a uniform $1500 \mathrm{~m} / \mathrm{s}$ for the velocity in water.

\section{Results}

\subsection{Petrography and ages of sea-bottom rock samples}

A petrographic characterization of sea-bottom rock samples is displayed in Tableau 1 and Fig. 3. The present database integrates the description of newly collected samples and the reappraisal of the rock material sampled by Froget (1972).

The sea-bottom rock sample dataset can be subdivided into three groups: 1) biostratigraphically dated samples, 2) samples that are not directly dated by biostratigraphic means but whose stratigraphic attribution can be unambiguously inferred by analogy with onshore formations displaying similar lithology and/or depositional facies, and 3) samples of uncertain stratigraphic attribution.

In Tableau 1 are reported the key benthonic foraminifer taxa used for the biostratigraphic dating of first group samples. These sample ages range from Lower Cretaceous (Valanginian) to Pleistocene.

The main lithologies/facies that allowed a stratigraphic attribution to be inferred from second group sea-bottom rocks are: 1) metamorphic rocks that are mineralogically and texturally similar to the Paleozoic Six-Fours phyllades, 2) Siliceous limestones with spongespicula that are regionally in basinal Upper Aptian to Albian deposits (Blanc and Blanc-Vernet 1966), 3) Palustrine limestones with charophytes and fresh-water mollusks that are known onshore, in the Oligocene Marseille basin, within the "Calcaire de l'Estaque" formation of Rupelian age (Nury 1988), and 4) Coral, foraminiferal, red algal floatstones that are common 
in the Late Oligocene-Lower Miocene reef-bearing carbonate system from the Nerthe Massif (Oudet et al. 2010).

\subsection{Definition of the seismo-stratigraphic units}

The interpretation of major unconformities and seismic facies allowed nine seismostratigraphic units to be defined within the Provence continental shelf (Fig 4).

Basement Unit (Us): The basement unit is characterized by an unstructured, chaotic seismic facies. On the basis of sea-bottom rock samples and coastal outcrop data this seismic unit may include various lithologies and various stratigraphic intervals: Paleozoic metamorphic rocks and Mesozoic (pre-Cretaceous) carbonates (Fig. 4, 5 and 6).

Unit 0 (UO): The unit UO is composed, in its lower part, of a set of tectonically deformed and poorly continuous reflectors overlying the acoustic basement (sparker profiles only). This stratified interval (UOa) is interpreted to represent Berriasian to Hauterivian limestone and argillaceous limestones. A sea-bottom sample collected within this stratified seismic facies interval yelded a lower Valanginian age (Froget, 1974). The upper part of the unit which exhibits a non-stratified seismic facies (UOb) probably corresponds to Upper Hauterivian and Barremian massive limestones and dolomites (Figures 5, 7, 8, 9, 10 and 11). UOa and UOb subunits cannot be separated in airgun profiles.

Unit 1 (U1): Unit 1 is characterized, in both sparker and airgun profiles, by a low frequency layered seismic facies with continuous, parallel and folded high-amplitude reflectors (Fig. 4). Unit 1 is identified in the Central area and conformably lies on the basement unit (Fig. 6, 7 and 8 ) or can be laterally bounded by faults (Fig. 5 and 6). At the vicinity of the present-day Cassidaigne canyon, Unit 1 is eroded by a steeply-flanked deep incision (225 m; Fig. 11b), whereas in the Calanque shelf, it is topped by a nearly horizontal flat angular unconformity truncating the folded reflectors (Fig. 5 and 6) and minor incisions ( $35 \mathrm{~m}$; Fig. 5). Unit 1 is interpreted to represent Aptian basinal limestones and marls on the basis of the following criteria: 1) the layered seismic facies suggesting high-frequency vertical lithologic contrasts, 2) the conformable contact with the acoustic basement is regionally consistent with the vertical succession from tight Barremian platform carbonates to Aptian basinal 
marls/limestone alternations, that is related to the drowning of the Urgonian platform and 3) the occurrence of sponge-rich siliceous limestones (samples CAS09-CR60 and samples a1, a2, a3; Froget 1974; Table 1 and Fig. 3) at the top of Unit 1, that exhibit a similar facies to that known onshore in the Upper Aptian and Albian.

Unit 2 (U2): Unit 2 unconformably overlies the Unit 1 (Fig. 6). On VHR seismic profiles it is characterized, in the lower part of the unit, by a stratified seismic facies with high frequency, medium amplitude, continuous reflectors. In the upper part of the unit, reflectors display higher amplitudes together with a lower continuity (Fig. 8). In airgun profiles, Unit 2 displays a more transparent seismic facies with very low amplitude reflectors. Unit 2 is recognized South of the Soubeyranes cliffs, between Cassis and Saint-Cyr-sur-Mer as well as South of the Riou island. Unit 2 is correlated to the Upper Cretaceous deposits sedimentary cover on the basis of: 1) the unconformable contact above the Aptian, 2) the well-stratified seismic facies of the lower Unit 2 that is consistent with the Cenomanian-Lower Turonian marls, 3) the more chaotic seismic expression of the upper Unit 2 that could represent the Upper Turonian to Coniacian deposits characterized by interdigitized basinal autochtonous quartzrich carbonates, redeposited carbonate breccia and terrigenous conglomerates (Floquet and Hennuy 2003; Fig. 6). The sampling of the base of the unit shows (Samples CAS09-CR57bis and CAS09-CR65; Table 1; Fig. 3), the occurrence of echinodermal, red algal, foraminiferal glauconitic packstones exhibiting a Hedbergella-Rotalipora assemblage that suggests a Cenomanian age.

Unit 3 (U3): Unit 3 is characterized by a moderate frequency, stratified seismic facies with continuous, parallel and folded reflectors (Fig. 4). In the western area, Unit 3 is laterally limited by the basement unit (Us) and is topped by a horizontal unconformity that truncates the folded and faulted reflectors (Fig. 9a and 9b). In the Bay of Marseille, Unit 3 forms a wide syncline whereas South of the Frioul islands, it is extremely deformed and cut by sub-vertical faults thus resulting in a more chaotic seismic facies (Fig. 9a and 9b). Unit 3 is interpreted to represent Oligocene fluvio-lacustrine deposits on the basis of the following criteria: 1) the layered high to low seismic facies is consistent with the strong lithologic contrasts between limestones, clays, sandstones and conglomerates, 2) the unconformable contact with the basement unit is regionally consistent with the onshore Oligocene deposits overlying tight Mesozoïc carbonates, 3) the land-sea structural continuity with the Marseille Oligocene basin, 3) the occurrence of ostracods and gastropods-bearing lacustrine-palustrine 
limestones (samples CAS09-CR18 and CAS09-CR-19; Table 1) at the top of Unit 3 that exhibit a similar depositional facies to those known onshore in the Rupelian stage (Nury 1990).

Unit 4 (U4): Unit 4 is characterized by a stratified seismic facies with high-frequency, continuous reflectors onlapping Unit UO or conformably overlying Unit 3 (Fig. 4, 9a, and 10).

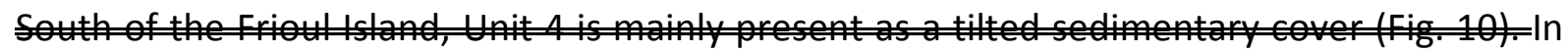

the Northern Bay of Marseille, Unit 4 is affected by post-depositional folding and is preserved along the main syncline axis (Fig. 9a). The top of the seismic unit is an angular unconformity that post-dates the deformation. Structural cross-sections along a land to sea transect in the Nerthe massif (Oudet 2008) allowed the Unit 4 to be attributed to the syn-rift period, which is dated Chattian to early Burdigalian (Oudet et al. 2010). Such an interpretation is consistent 1 ) with the observation that Unit 4 represents most of the halfgraben infill and 2) with the presence of Coral-Foraminiferal packstones in sea-bottom cores that are similar in facies with Late Oligocene-Early Miocene shallow marine deposits from the Nerthe coast (Sample CAS09-CR17; Tab. 1; Fig. 3).

Unit 5 (U5): Unit 5 is characterized by a high frequency, stratified seismic facies (Fig. 4) onlapping the tectonically deformed units $\mathrm{U} 4, \mathrm{U} 1$ and the acoustic basement. At top of the seismic Unit 5, a flat horizontal angular unconformity or incised surface (Fig. 6, 7 and 10) truncates the internal reflectors (toplap). Unit 5 is interpreted to belong to the Post-rift antePliocene formation that corresponds to Burdigalian to Tortonian ages (Oudet et al. 2010) on the basis of: 1) its stratigraphical position above the Syn-rift unit and below deep valley-like incisions attributable to Messinian and/or Quaternary incisions, 2) the vicinity of Burdigalian to Tortonian onshore deposits of the Nerthe massif and Berre lake in structural continuity with the offshore seismic Unit 5.

Unit 6 sensu stricto (U6): Unit 6 is identified in the whole Provence shelf and is characterized by a stratified facies with high amplitude, highly continuous, horizontal to sigmoidal reflectors onlapping UO to U5 units (Fig. 4 to 12). Its top coincides with the seabed. On the Western and Central sectors, reflectors are mainly horizontal and the unit is based by a flat, horizontal angular unconformity. On the Eastern area, Unit 6 is characterized by sigmoidal reflectors to the East, and wavy reflectors to the West (Fig. 12). All geological samples acquired at the level of Unit 6 give Pleistocene and Pliocene ages (samples of Froget 1974) and CASSEIS samples CAS09-CR01 to CR05, CR08 to CR11, CR22, CR23, CR27, CR28, CR30, CR34, CR44 to CR47, CR50, CR74 (Table 1; Fig. 3) 
Unit $\mathbf{6 b}\left(\mathbf{U} \underline{6}_{b}\right):$ In the Eastern area, we separate U6 unit from a basal U6 $6_{b}$ unit, which display a higher amplitude and lower frequency stratified seismic facies that cannot be directly dated (Fig. 4 and 12). The U6b is onlapped by the U6 sensu stricto.

The $U \sigma_{b}$ is characterized by high-amplitude, low-frequency stratified seismic facies while the U6 sensu stricto exhibits higher-frequency and lower-amplitude. The boundary between the $\mathrm{U} 6_{\mathrm{b}}$ and $\mathrm{U} 6$ s.s. do not display strong evidences of erosional features. The U6 s.s. is made of a thick set of westward prograding reflectors capped by a toplap surface that is overlain by nearly horizontal reflectors. Sea-bottom samples collected in the prograding part of this subunit provided a Pliocene age on the basis of benthic foraminifera (Froget 1972, Blanc-Vernet 1969). All samples collected in the uppermost horizontal reflectors interval yelded Pleistocene or Holocene age. The age of the $U 6_{b}$ is poorly constrained since no rock core sample is available from this interval. No evidence of syn-sedimentary tectonic feature is observed within this sub-unit, suggesting that sediments passively infilled a previously formed topography. Two hypothesis are proposed to date this lower sub-unit (Fig. 12b, 12c, 16):

(H1) An Oligocene hypothesis that is supported by the presence of Oligocene sediments in the onshore Bandol bay.

(H2) A Pliocene hypothesis that is supported by the strongly erosional pattern of the basal surface that would be consistent with the regionally well-known Messinian incision, and the presence of post-Messinian conglomerates in the onshore Bandol bay (Coulon 1967).

\subsection{Distribution of geological formations and structures of the Provence continental shelf}

Seismic interpretation of the whole dataset and core data allows a geological map of the Provence continental shelf to be performed (Fig. 14). By convention, the geological mapping corresponds to a cutaway under the Plio-Quaternary sequence when its thickness is larger than 100 ms TWTT. It gives a new geological view of the offshore domain from the shore up to the shelf break that was not available up to date.

\subsubsection{Western area: the Marseille Bay and South of the Frioul Islands}

Interpreted seismic profiles showing the Marseille shelf are displayed in figures 9a, 9b, 10, and 11b, 11c. The offshore Tertiary Marseille basin is subdivided into two sub-basins 
separated by an East-West-trending horst forming the Frioul islands and the Notre-Dame-dela-Garde massif. In the Marseille bay (northern sub-basin; Fig. 9a), Oligocene (U3), OligoMiocene syn-rift (U4) units form a wide NE-SW-trending syncline whereas in the South of the Frioul islands (southern sub-basin) Oligocene deposits are strongly deformed and affected by reverse faults. In both sub-basins, a thin (0 to $0.03 \mathrm{~s}$ TWTT) Plio-Quaternary unit (U6) unconformably overlies the acoustic basement, and the U3 and U4 seismic units. In the western part of the offshore Marseille Tertiary basin, the Mesozoic limestones (basement unit) form horst structures, while Syn-rift unit (U4) corresponds to half-graben infills, truncated at the top by a flat erosion surface that is conformed to the present day sea floor topography. Miocene post-rift unit (U5) unconformably overlies syn-rift U4 unit and forms a transgressive-aggrading wedge preserved on the shelf edge. Plio-Quaternary deposits (U6) are thin and are based by a gently uneven erosional surface.

The base Plio-Quaternary seismic reflector highlights the absence of deep fluvial incision on the Provence shelf in the Marseille bay and South of the Frioul islands, thus suggesting that the present-day Huveaune river did not yet exist during the Messinian salinity crisis (Fig. 9b). Further to the West, the base of the Plio-Quaternary unit is changing into a deep and strongly uneven surface (Fig. 11c: Marion03 profile) that is interpreted as the Messinian Rhone canyon incision (Lofi 2005).

\subsubsection{Central area: the Calanque shelf}

Close to the Calanque coastline, the CAS09-spk6 seismic profile (Fig. 5) exhibits very deformed Aptian (U1), Neocomian (U0a) units that are affected by nearly vertical faults. The unit UO corresponds to tight pre-Aptian carbonates extensively outcropping in the whole Calanques Massif and on the Riou Island (Fig. 1 and 2). Onland, the Luminy fault system displays the same tectonic pattern with a maximum $800 \mathrm{~m}$ vertical offset (Guieu 1968). PlioQuaternary deposits are based by a relatively flat, nearly horizontal surface showing locally narrow and shallow incisions (maximum 0.2s TWT) that are laterally connected to the onshore Calanques dry valleys.

South of the Riou Island, Aptian (U1) and Upper Cretaceous (U2) units form an East-West trending syncline bounded to the North and to the South by nearly sub-vertical faults (Fig. 6, $7 a, 11 a, 12 a)$. The south of the basin is overlain by a transgressive-aggrading wedge consisting in Miocene post-rift deposits (U5 unit) that developped on the shelf edge by 
onlapping the basement unit (Fig. 6) and the Aptian unit (Fig. 7a-b). The base of U6 unit is characterized by a relatively sub-horizontal and smooth seismic horizon with locally deep incised valleys (Fig. 7b). The depth of these valleys can reach a depth up to 0.450s TWT. We supposed that these valleys are the markers of the MSC.

\subsubsection{Eastern area: the Blauquière shelf and the Cassidaigne canyon}

South of the Soubeyranes cliffs, between Cassis and La Ciotat, VHR seismic profiles exhibit the typical stratigraphic succession of the Beausset unit (Fig. 8), from the Urgonian (Us), to the Aptian marls (U1) and the upper Cretaceous marls, sandstones and limestones (U2), gently dipping towards the SE. These strata are truncated by an unconformity forming the base of Plio-Quaternary (U6) deposits. Further to the South (Fig. $11 \mathrm{a}$-b) the Cassidaigne canyon incises the margin down to 0.9s TWTT. The canyon incised the U1 Aptian unit (Northwestern flank) (Fig. 11a,b; Fig. 13) and the unit U0, which consists of Lower Cretaceous tight limestones (Northern flank), Triassic and Jurassic limestones and dolomites representing the westward extension of the Bandol thrusts (Northeastern flank), and Paleozoic metamorphic (Southeastern flank) and sedimentary siliciclastic rocks (Southwestern flank).

East of the Cassidaigne canyon, the Blauquières shelf is made of Paleozoic metamorphic and sedimentary rocks that are deeply incised by up to 0.6s TWTT deep canyons which are filled with a thick sedimentary unit (Fig. 11b; Fig. 13). The main filled valley ("Bandol Canyon") is a composite valley structured in two East-West-trending canyons (Fig. 12c to 16) whose sedimentary infill can be subdivided into 2 sub-units: the Unit U6 sensu stricto onlaps the Unit $U 6_{b}$.

\subsection{Tectonostratigraphic framework of the Provence continental shelf}

In the Eastern Area, the metamorphic formation observed offshore (Banc des Blauquières area) represents the westward termination of the Hercynian basement outcropping at the Sicié Cape. It is incised to the North by the Bandol canyon and to the West by the Cassidaigne canyon. Offshore Bandol, slice thrusts structures affecting Mesozoïc formations and prolonging those outcropping onshore are deeply incised by the Bandol Canyon, forming its Northern flank. The Bandol Canyon formed preferentially at the boundary between the Hercynian basement and the Mesozoic slice thrusts. 
If the U6b is an Oligocene formation (hypothesis 1), it suggests that the formation of the Bandol canyon was controlled by Oligocene erosion of a canyon or syn-rift grabens. If the U6b belong to the Plio-Quaternary formation, (hypothesis 2), the Bandol canyon could have developed in a soft formation located between the Hercynian basement and the Bandol slice thrust. During the Pliocene, the Bandol canyon was totally filled with 500 to $700 \mathrm{~m}$ of prograding to aggrading marine deposits (Fig. 12b and 12c). Prior studies focused on the carbonate nature of the Pliocene and Pleistocene sedimentation in this area (Table 1: R109R110 red algual calcarenite Pliocene samples; Froget 1974). The Cassidaigne canyon, which is deeper and still erosive downstream, is only partially filled by sediments coming from the Bandol canyon.

The northern part of Eastern area represents the southern termination of the upper Cretaceous Beausset syncline. The southern boundary of the Beausset syncline is the NE-SWtrending faults systems of the Calanques massif that corresponds also to the northern boundary of the Bandol slice thrusts unit (Fig15A).

The Central Area is subdivided into 3 main tectono-stratigraphic domains: 1) the northern part represents the offshore termination of the Calanque massif and consists of Upper Jurassic-Lower Cretaceous carbonates, 2) South of the Riou fault, Lower and Upper Cretaceous deposits are structured into an E-W-trending syncline (Riou syncline) affected by E-W to NW-SE vertical faults, 3) the southernmost part of the continental shelf exhibits an EW-trending horst structure that probably consists of Paleozoic rocks. The high angle faults suggested in the cross section (Fig. 15B) might relate to the Miocene collapse of Pyrenean thrusts, as documented by Toutin-Morin and Bonijoly, $(1992,1994)$ and Roure and Colletta (1996). These faults are scelled by the Middle Burdigalian in the Nerthe area (Oudet et al., 2010).

The Southern part of the continental shelf is transgressed by Neogene deposits, onlapping both the Paleozoic basement and Cretaceous deposits from the Riou syncline. Most of the Cassidaigne canyon formed within Paleozoic metamorphic and sedimentary rocks. Only the western head of the Canyon developed into soft Mesozoïc formations (Aptian argillaceous limestones and marls and possibly Jurassic carbonates), displaying a bad-land erosive structure on this part of the canyon. The continuity of the Calanques faults systems from the onshore to offshore area is evidenced from the present dataset. This NW-SE-trending fault 
system structures the area between the coastline and the head of the Cassidaigne canyon into horsts and grabens, with vertical offsets of hundreds of meters (Fig15B).

The western area corresponds to the offshore termination of the Oligocene Marseille basin. It is bounded to the SE by a nearly vertical SW-NE trending fault and can be subdivided into two sub-basins, separated by an ENE-WSW horst dominantly made of Urgonian limestones (Barremian in age). The Frioul islands and the Notre-Dame-de-la-Garde coastal massif are the subaerially exposed parts of this horst. The northern sub-basin is characterized by an ENE-WSW syncline formed by Oligocene and Aquitanian siliciclastic and carbonate deposits. The southern sub-basin is characterized by highly faulted and folded Oligo-Aquitanian deposits. These two sub-basins are transgressed on their western side by the Aquitanian showing a syn-rift deformation. To the South and to the West, Oligocene and Aquitanian deposits are overlain by transgressive post-rift Miocene sedimentation. (Fig15C)

\subsection{Seismic geomorphology of the Messinian Provence shelf}

\subsubsection{Morphology and significance of the base Plio-Quaternary surface}

The geometry of plane erosional truncations within Plio-Quaternary unit (U6 s.s.) characterizes the flat and slowly varying bathymetry of the sector. This wide margin ( 400 $\mathrm{km}^{2}$ ) is quite homogeneous on a morphological point of view (Fig. 1). On the Provence continental shelf, the base Plio-Quaternary surface (Fig. 16) displays a flat morphology, gently dipping toward the South, with deep incised valleys (Planier, Cassidaigne, and Bandol canyons) interpreted as subaerial canyons formed during the Messinian Salinity Crisis. The depth of the flat surface ranges from $50 \mathrm{~m}$ to $200 \mathrm{~m}$ and its slope ranges from 0.8 to $1.2 \%$. Below this surface, the Hercynian basement (Fig. 11 and 12) to the Mesozoic (Fig. 5 to 11), and Oligo-Miocene deposits (Fig.9 and 10) are truncated.

Such a strongly erosive and flat surface is highly consistent with a marine erosional surface that developed above the permanent wave-base, during a single or various transgressive phases. If one assumes a maximum water-depth of $20 \mathrm{~m}$ for the permanent wave-base in the Mediterranean Sea (Peres and Picard 1964), the maximum depth of the flat surface (200 $\mathrm{m}$ below present-day sea-level) is significantly deeper than the expected wave-base during the major Quaternary sea-level lowstands $(140 \mathrm{~m})$. As a consequence, the flat area of the base Plio-Quaternary surface is interpreted as a pre-Quaternary wave-cut surface. It post- 
dates the post-rift deposits (Fig. 10, 11). This surface is correlated with the post-MSC planation surface from the Gulf of Lion evidenced by Bache et al. $(2009,2012)$ and interpreted as having formed by wave-erosion processes during a post-Messinian base-level rise. The shallowest part of this erosional surface (above 140m) is stacked with Quaternary transgressions surfaces. South of Cassis, the base Plio-Quaternary exhibits a canyon morphology (Fig 11a,b). This canyon is subdivided into an E-W incision (Bandol canyon) and a $\mathrm{N}$-S incision (Cassidaigne canyon). The Bandol Canyon is a $20 \mathrm{~km}$ long valley-like incision with a depth ranging from 150 to 500 m (Oligocene canyon incised by Messinian sea level fall, Hypothese 1) or $700 \mathrm{~m}$ (Messinian canyon, hypothese 2) below present-day sea-level, and a mean slope averaging $2.75 \%$ towards the West (Fig. 16). An additional incision, of minor extension and connected to the Bandol Canyon is evidenced in the Bandol bay, displaying an $\mathrm{E}-\mathrm{W}$ direction and depths ranging from $350 \mathrm{~m}$ (Hypothesis 1) to $550 \mathrm{~m}$ (Hypothesis 2). The Messinian origin of the Cassidaigne-Bandol canyon (in both hypotheses) is suggested by 1) the shape of the incision ( $>150 \mathrm{~m}$ ) and 2 ) the Pliocene and Quaternary ages of the overlying deposits as yelded in the sea-bottom cores.

The base of Plio-Quaternary deposits on the Provence continental shelf is therefore interpreted as a polyphased surface related to at least two major erosional events: 1) the canyons formed during the major Messinian sea-level lowstand by fluvial erosional processes, and 2) the flat shelf formed during the Zanclean transgression, with a possible reactivation in its proximal part during the major Quaternary transgressions, a result of wave-induced marine erosional processes.

\subsubsection{Lithologic and structural control on the Provence shelf during the Messinian}

Present-day morphology of Cassidaigne canyon is illustrated figure 17 and Messinian erosion of Cassidaigne and Bandol Canyons are illustrated figures 16 and 18. A 3D modeling of the Messinian incision surface has been realized with gOcad software (Fig. 18A). The 3D geometry of the canyons controls the 3D architecture of the Plio-Quaternary sedimentary filling (Fig. 18A and B).

The Cassidaigne and Bandol canyons development is strongly influenced by lithology and structures of the basement (Fig. 13 and 14). The western head of the Cassidaigne canyon developed into the soft Aptian marls. The head displays a bad-land erosive structure with gullies on the eastern and western sides and a scar on the northeast (Fig 17). Except the 
head of the canyon, the Cassidaigne canyon developed mainly in Paleozoic terrigenous formations (Carboniferous and Permian) and metamorphic rocks. The Cassidaigne canyon is located at the western termination of the Cap Sicié Paleozoic tectonic unit (Fig. 14). Messinian fluvial systems probably have incised preferentially Paleozoic softer rocks such as phyllades and pelites rather than the tight Jurassic and Cretaceous limestones.

The Bandol canyon is also probably controlled by sub-outcropping rocks lithologies and structural orientations. If we consider that the basal unit $\left(U \sigma_{b}\right)$ of the sedimentary filling of the Bandol canyon is an Oligocene formation (hypothesis 1 ), then the $U \sigma_{b}$ corresponds to syn-rift sedimentary deposits, infilling a E-W-trending graben or an Oligocene canyon as previously described on the western Corsica (Ferrandini, personal communication). The U6 may be dominated by moderately consolidated, soft carbonate and detrital material and are preferentially affected by Messinian erosion processes, while more consolidated rocks, such as Mesozoic limestone have been preserved on marginal horsts. According to both hypothesis, the shelf is incised during in Late Paleozoïc terrigenous deposits (Carboniferous and Permian) located between Paleozoic crystalline basement and Bandol thrusting sedimentary rocks. The E-W orientation of the Bandol canyon derived from the structuration of the Paleozoic sedimentary cover into E-W-trendings folds, during the Pyrenean compressive phase (Fig16A)

\section{Discussion: reconstitution of the Messinian hydrographic network and karst drainage}

Isobaths maps of the seabed and of the base of Plio-Quaternary deposits evidence various geomorphological features that allow a paleohydrographic reconstruction to be inferred for Messinian times. The most paradoxal geomorphological features of the present-day Provence continental shelf are the lack of incision offshore the Huveaune river (Fig. 9b and 15), and the apparent lack of connexion of the Cassidaigne canyon with any fluvial system onshore. A former hypothesis for the Cassidaigne formation (Audra et al. 2004) is that of a canyon incision during the MSC by the erosive action of a river sourced by the karst system of Port-Miou (Fig. 19). As a consequence, the head of the canyon was interpreted as a karst pocket valley. Pliocene flooding of the Provence shelf and the high eustatic level would have 
stopped the hydraulic system, leading to the formation of the present-day Port-Miou spring (Cavalera et al, 2006). This hypothesis requires the existence of a continuous karstic network that developed between the present-day coastline and the head of the canyon. However, from the new geological map of the Provence shelf (Fig. 14) a NW-SE highly faulted area with vertical offsets of hundred of meters is located at the level to porous or karstified carbonate formations (Barremian, Neocomian) to marls (Aptian) and marly limestones (Neocomian). In addition, the present study shows that the Messinian Cassidaigne canyon is connected to the East to the E-W oriented Bandol canyon. The Cassidaigne and Bandol Messinian canyons must be considered as two segments of a single canyon (the Cassidaigne-Bandol canyon). As a consequence, the paleo-hydrographic system responsible for the formation of the major part of the present-day Cassidaigne canyon must be searched East of the canyon, and not North of the canyon.

Only the head of the Cassidaigne canyon, incising Mesozoïc carbonate-rich formations, may be related to karst processes. The Messinian Bandol canyon is subdivided into two valleys situated in front of three coastal rivers onshore, the Grand Vallat, the Reppe and the Gapeau rivers. The first two rivers which are of minor importance with moderate present-day flow (mean flow of 70 to $150 \mathrm{~L} / \mathrm{s}$ ). Such rivers, if present at Messinian times, may have contributed to the formation of the Cassidaigne-Bandol canyon but cannot alone explain the whole incision. In contrast, the Gapeau river is a major coastal river, located between the South of Sainte Baume massif and the coast, with a mean flow of $1300 \mathrm{~L} / \mathrm{s}$. Its present-day mouth is localized in the town of Hyeres, $20 \mathrm{~km}$ East from our study area, but during the Quaternary the river bed moved (Journot 1948) from Toulon, East of Sicié Cape, to its present-day location in La Crau area (Fig. 19). During the Messinian, the Gapeau river could have been the main river responsible for the formation of the Cassidaigne-Bandol canyon, by-passing the Sicié Cape flat surface, and joining the Reppe and Grand Vallat paleo-canyons. The absence of Messinian canyons offshore the Huveaune river mouth is a major geomorphological paradox in the Provence continental margin. The base of Plio-Quaternary surface exhibits a planar morphology, truncating Oligocene and Miocene deposits. Onshore, the Huveaune river only displays Quaternary fluvial terraces (Bonifay 1967), and no Messinian canyon was evidenced. We propose three hypotheses to explain the lack of Huveaune Messinian incision offshore and onshore (Fig. 19): (1) During the Messinian, Huveaune river displayed a different hydrography: the river could have flown south of 
Aubagne locality, thus avoiding the Marseille basin, either in surface, by-passing the Douard canyon, or within a karstic network being captured by the endokarst into the Aubagne sinkhole. (2) The Huveaune river displayed the same hydrography as in present-days, but was captured by endokarsts close to the coast, and its spring was situated in the Planier canyon, functioning as a karst pocket-valley. (3) Messinian topographic gradient and/or climate were different from today, and the Huveaune river did not exist during this period.

The two first hypotheses have in common an extremely important outcome: in all cases, the meteoric water infiltrates through the carbonate formations, and is exported across the endokarst, either through sinkholes, either directly by infiltration through the ground. Groundwater drainage is constrained by the position of the base level, the rocks permeability and geological structures. During the MSC, the base level was more than 1500 meters deep, in the Cassidaigne-Bandol canyon. Two major structural elements constrain the groundwater flow (Fig. 14): the Paleozoic basement south of Bandol canyon which forms an impermeable boundary, and the highly faulted zone north of Cassidaigne canyon that implies structural contacts between permeable carbonate formations and low permeability marls. This tectono-stratigraphic architecture can lead to either large voids favorable to karst flow (Audra and Palmer 2011; Gilli 2010) or otherwise to zones of reduced permeability that may represent hydraulic barriers between Port-Miou spring and Cassidaigne canyon.

In carbonate environment, the groundwater conventionally flows out at karstic springs. The springs connected to a valley, or a canyon, can generate a pocket valley growing upstream. Several morphology of pockets valleys emerge in figure 19, connected to the head of the Cassidaigne canyon and on the right side of the Bandol canyon. This drainage system has been described in the karst connected to the Rhône Valley during the MSC (Mocochain et al. 2011, Mocochain et al. 2006). For example, the Fontaine de Vaucluse, which is the largest spring in France, was drained during the MSC by springs close to the base level during low flow. During high flow, the lowest springs are unable to carry the entire discharge; water table rises, water floods the epiphreatic zone, rises in phreatic lift tubes, leading to per ascensum speleogenesis, and eventually emerges at overflow springs.

In the bay of Cassis, the submarine spring of Port-Miou has been explored to a depth of $223 \mathrm{~m}$ by cave divers (Meniscus 2012). It shows a shaft developed at a depth deeper than that reaches during the quaternary regressions. The deep shaft of Port-Miou could then exist during the MSC, forming a shaft for per ascensum overflow. The marly-limestones found in 
the bay of Cassis would favor the head losses in the flow to the lowest springs, with overflow in the karst above the saturated zone. In the present state, the rise of the base level that followed the MSC, and the partly filled canyon, force the water to use the past overflow route to form a perennial submarine spring.

\section{Conclusion}

The seismic imaging of the Provence continental shelf and the integration of offshore and onshore geology allow a better understanding of this key structural domain. A geological map and a depth map of the base of Plio-Quaternary deposits are presented for the first time in this area. The geological mapping of the Provence continental shelf is based on the definition of nine seismo-stratigraphic units. The base Plio-Quaternary surface is a polyphased unconformity, with deep canyons developed by fluvial erosion during the Messinian, and wave-cut surfaces, induced by post-Messinian transgressions. During the Messinian Salinity Crisis, the Cassidaigne-Bandol canyon has an E-W segment in its upper part (Bandol canyon S.S) and a N-S segment in its lower part (Cassidaigne canyon S.S) corresponding to the present-day canyon. The Bandol canyon is filled by Plio-Quaternary mixed carbonate-siliciclastic deposits.

The location and shape of the Cassidaigne-Bandol canyon compared to the tectonostratigraphic architecture of the Provence continental shelf suggests a strong lithologic and structural control on the development of the Provence canyons during the Messinian erosion.

A map of the Messinian paleo-drainage network is proposed to explain the presence of deep canyons in the Eastern area and the absence of incision in the Western area.

An underground karst drainage scheme is proposed, linked with the current submarine PortMiou spring.

Such results provide a new insight into the tectonic and stratigraphic framework of the Provence margin but also into the geodynamic and hydrographic evolution of this transitional area between the Rhone margin of Gulf of Lion and the Liguria margin.

\section{Aknowledgements :}


Authors thank the captains and the crew of the R/V TETHYS II ship, the CIRMED, IUEM, INSU/Villefranche sur Mer for the technical support, technician for seismic acquisition (INSU and BRGM), Action Marges, BRGM, KarstEAU, Lionel Marié, Guy Tronchetti, Antoine Faure, and Master SET students for their contribution to the seismic acquisition in 2007 and 2009 and the biostratigraphy.

\section{References}

Arthaud F., Séguret M., 1981. Les structures pyrénéennes du Languedoc et du golfe du Lion (Sud de la France), Bull. Soc. Géol. Fr. 23 51-63.

Audra P., Mocochain L., Camus H., Gilli E., Clauzon G., Bigot J.Y, 2004. The effect of the Messinian Deep Stage on karst development around the Mediterranean Sea. Examples from Southern France. Geodinamica Acta, 17, 6, p.27-38.

Audra P., Palmer A.N., 2011. The pattern of caves: controls of epigenic speleogenesis, Géomorphologie : relief, processus, environnement, 4/2011, 359-378.

Bache, F., Olivet, J.L., Gorini, C., Rabineau, M., Baztan, J., Aslanian, D., Suc, J.P., 2009. The Messinian erosional and salinity crises: view from the Provence Basin (Gulf of Lions, Western Mediterranean). Earth Planet. Sci. Lett. 286, 139-157

Bache, F., Olivet, J.L., Gorini, C., Aslanian, D., Labails, C., Rabineau, M., 2010. Evolution of rifted continental margins: the case of the Gulf of Lions (Western Mediterranean Basin). Earth and Planetary Science Letters 292, 345e356.

Bache F, Popescu S-M, Rabineau M, Gorini C, Suc J-P, Clauzon G, Olivet J-L, Rubino J-L, Melinte-Dobrinescu M, Estrada F, Londeix L, Armijo R, Meyer B , Jolivet L, Jouannic G, Leroux E, Aslanian D, Baztan J, Dos Reis A, Mocochain L, Dumurdžanov N, Zagorchev I, Lesić V, Tomić D, Çağatay M. Brun J-P, Sokoutis D, Ucarkus $G$ and Çakir Z, 2012. A two-step process for the reflooding of the Mediterranean after the Messinian Salinity Crisis, Basin Research 24, 125153. doi: 10.1111/j.1365-2117.2011.00521.x.

Barber, P.M.,1981. Messinian subaerial erosion of the Proto-Nile delta. Mar. Geol. 44, 253272.

Bellaiche G., Coumes F., Irr F., Roure F. et Vanney J.R., 1978. Structure des canyons sousmarins provençaux. Sédimentation, diagénèse et érosion pendant le Quaternaire,.C.R. Acad. Sc. Paris, 286, D, 1779-1782. 
Bellaiche G., Coumes F., Irr F., Roure F. et Vanney J.R., 1979. Structure of the French Riveria submarine canyons: evidence of a polygenetic history from a submersible study ("Cyaligure" campaign). Marine Geology, 31, M5-M12.

Bellaiche G. Pautot G., Aloisi J.-C., Coutelle A., Degiovanni C., Droz L., Gaullier V., 1991. Bathymétrie au "Seabeam " de la marge continentale méditerranéenne au large de la France métropolitaine : Premiers résultats de la campagne « Mesea I». C. R. Ac. Sc., Paris. T. 313 ; sér. II 547-556

Benson, R.H., Rakic-El Bied, K., Bonaduce, G., 1991. An important current reversal (influx) in the Rifian Corridor (Morocco) at the Tortonian-Messinian boundary: the end of the Tethys Ocean. Paleoceanography 6 (1), 164-192.

Berné., S., Loubrieu, B., and the CALMAR shipboard party, 1999. Canyons et processus sédimentaires récents sur la marge occidentale du Golfe du Lion. Premiers résultats de la campagne Calmar. C. R. Acad. Sci. Paris, 328, 471-477.

Bigot-Cormier, F., Sage, F., Sosson, M., Déverchère, J., Ferrandini, M., Guennoc, P., Popoff, M., Stéphan, J.-F., 2004. Déformations pliocènes de la marge nord-Ligure (France): les conséquences d'un chevauchement crustal sub-alpin. Bulletin de la Société Géologique de France 175, 197e211.

Blanc P.-L., 2002. The opening of the Plio-Quaternary Gilbraltar Strait: assessing the size of a cataclysm. Geodin. Acta 15, 303-317.

Blanc et Blanc-Vernet, 1966. Affleurements sous-marins du Barrémien et de l'Aptien dans la baie de Cassis, C. R. Acad. Sc. Paris, t. 262, pp. 1398-1399.

Bonifay E., 1967. La tectonique récente du bassin de Marseille dans le cadre de l'évolution post-miocène du littoral méditerranéen français. Bull. Soc. Géol. Fr., (7), IX: 549-560.

Carminati, E., Wortel, M. J. R., Meijer, P. T.,Sabadini, R. 1998a. The two-stage opening of the western-central Mediterranean basins: a forward modeling test to a new evolutionary model. Earth and Planetary Science Letters 160: 667-679.

Carminati, E., Wortel, M. J. R., Spakman, W., Sabadini, R., 1998b. - The role of slab detachment processes in the opening of the western-central Mediterranean basins: some geological and geophysical evidence. Earth and Planetary Science Letters 160: 651-665.

Cavalera T., Arfib B., \& Gilli E., 2006. Ressource karstique côtière en méditerranée : les sources sous-marines de Port Miou et du Bestouan (Marseille - France). 8e coll. hydrogeol. en pays calcaire. Neuchâtel, 21-25 septembre 2006. 
Cita, M.B., Ryan,W.B.F. (Eds.), 1978. Messinian erosional surfaces in the Mediterranean. Marine Geology, vol. 27. 366 pp.

Clauzon, G., 1982. Le canyon messinien du Rhône: une preuve décisive du "dessicated deepbasin model" (Hsü, Cita et Ryan, 1973). Bull. Soc. geol. Fr. 24, 597-610.

Clauzon, G., 1973. The eustatic hypothesis and the pre-Pliocene cutting of the Rhône valley. In: Ryan, W.B.F., Hsü, K.J., et al. (Eds.), Initial Reports of Deep Sea Drilling Project, vol. 13. U.S. Government Printing Office, Washington, pp. 1251-1256.

Clauzon, G., Cravatte, J., 1985. Révision chronostratigraphique de la série pliocène traversée par le sondage Canet-1 (Pyrénées-Orientales): apports à la connaissance du Néogène du Roussillon. C.R. Acad. Sci., Paris 301-II, 1351-1354.

Collina-Girard J., 1999. Réseaux de vallées et prospection sismique : relation et implications structurales sur le plateau continental (Marseille, Bouches-du-Rhône, France). C. R. Acad. Sci. Paris, II, 329, 357-362

Debrand-Passard S., Courbouleix S., Lienhardt M-J., 1984. Synthèse géologique du Sud-Est de la France. Stratigraphie et paléogéographie. Mém. BRGM, 125-126.

Denizot, G., 1952. Le Pliocène dans la vallée du Rhône. Rev. Geogr. Lyon 27, 327-357.

Dos Reis A.T., 2001. La tectonique salifère et son influence sur l'architecture sédimentaire quaternaire de la marge du golfe du Lion - Méditerranée occidentale. PhD thesis, Université Pierre et Marie Curie - Paris VI, Paris, France, 373p.

Ducrot J., 1967. Premières données sur la structure profonde du Banc des Blauquières (région de la Ciotat, Bouches-du-Rhône). C.R. Soc. Geol. Fr., 3, 80.

Dupire S. 1985. Étude cartographique au 1/25000 de la zone sud du bassin de Marseille. Les Travertins de Marseille : aperçu géomorphologique et néotectonique. Thèse de 3ème cycle, Université de Provence, 104 p.

Froget C., 1967. Découvertes d'affleurements quaternaires anciens sur le Précontinent provençal au large de l'île de Riou. C.R. Acad. Sci. Paris, (D) 264, 2, p. 212-214.

Froget C., 1972. Exemples de diagenèse sous-marine dans les sédiments pliocènes et pléistocènes: dolomitization, ferruginisation (Méditerranée nord-occidentale, sud de Marseille). Examples of submarine diagenesis in Pliocene and Pleistocene sediments: dolomitization, ferruginisation (northwest Mediterranean, south of Marseille) Sedimentology, $19:$ 59-83. 
Froget C., 1974. Essai sur la géologie du précontinent de la Provence occidentale, Thèse de doctorat, Univ. Aix-Marseille. 219 p.

Gattacceca, J., Deino, A., Rizzo, R., Jones, D. S., Henry, B., Beaudoin, B., Vadeboin, F. 2007. Miocene rotation of Sardinia: New paleomagnetic and geochronological constraints and geodynamic implications. Earth and Planetary Science Letters.

Gennesseaux M., Lefebvre D., 1980. Le Golfe du Lion et le Paléo-Rhône messinien. Géologie Méditerranéenne. 7, 71-80.

Gilli E., 2010. Les grands vides karstiques souterrains. P. Audra ed. Karstologia Mémoire 19. p.54-55.

Gorini, C., 1993. Géodynamique d'une marge passive: le Golfe du Lion (Méditerranée Occidentale). Thèse de doctorat, Université Paul Sabatier, Toulouse, 256 pp.

Gorini, C., Le Marrec, A., Mauffret, A., 1993. Contribution to the structural and sedimentary history of the Gulf of Lions (Western Mediterranean) from the ECORS profiles, industrial seismic profiles and well data. Bull. Soc. géol. Fr. 164, 353-363.

Gorini, C., Lofi, J., Duvail, C., Dos Reis, T., Guennoc, P., Le Strat, P., Mauffret, A., 2005. The Late Messinian salinity crisis and Late Miocene tectonism: interaction and consequences on the physiography and post-rift evolution of the Gulf of Lions margin. Mar. Pet. Geol. 22, 695712.

Groupe Estocade, 1978. Messinian subaerial erosion of the Stoechades and St-Tropez canyons, a submersible study. Marine Geology, 27, 247-269.

Gueguen, E., Doglioni, C., Fernandez, M., 1998. On the post-25 Ma geodynamic evolution of the western Mediterranean. Tectonophysics 298, 259-269.

Guennoc, P., Debeglia, N., Gorini, C., Le Marrec, A.,Mauffret, A. 1994. Anatomie d'une marge passive jeune (Golfe du Lion - Sud France): apport des données géophysiques. Bulletin des Centres de Recherche, Exploration et Production de Elf Aquitaine 18: 33-57.

Guennoc P., Gorini C., Mauffret A. 2000. Histoire géologique du golfe du Lion et cartographie du rift oligo-aquitanien et de la surface messinienne. Géologie de la France 3: 67-97.

Hsü, K.J., 1972b. When the Mediterranean dried up. Sci. Am. 227, 44-51.

Hsü, K.J., 1973. The desiccated deep-basinmodel for theMessinianevents. In:Drooger, C.W. (Ed.), Messinian Events in the Mediterranean. North-Holland Publ. Co., Amsterdam, pp. 6067. 
Hsü, K.J., Cita, M.B., Ryan, W.B.F., 1973a. The origin of the Mediterranean evaporites. In: Ryan,W.B.F., Hsü, K.J, et al. (Eds.), Initial Reports of Deep Sea Drilling Project, vol.13. U.S. Government Printing Office, Washington, pp. 1203-1231.

Hsü, K.J., Montadert, L., Bernouilli, D., Cita, M.B., Erickson, A.,Garrison, R.E., Kid, R.B., Melieres, F., Muller, C., Wight, R., 1978. History of the Mediterranean salinity crisis. In: Hsu“, K.J., Montadert, L. (Eds.), Initial Reports of the Deep Sea Drilling Project, vol. 42 (1), pp. 1053-1078.

Jolivet, L., Faccenna, C., 2000. Mediterranean extension and the Africa-Eurasia collision. Tectonics 19, 1095-1106.

Jolivet, L., Augier, R., Robin, C., Suc, J.-P., Rouchy, J.M., 2006. Lithospheric-scale geodynamic context of the Messinian salinity crisis. Sedimentary Geology 188-189, 9-33.

Jolivet, L., et al., 2008. Subduction, convergence and the mode of backarc extension in the Mediterranean region. Bull. Soc. Géol. France 179 (6), 525-550.

Journot $\mathrm{Cl} .$, 1948. Le couloir périphérique des Maures. In: Annales de Géographie., t. 57, n³06. pp. 109-118. doi : 10.3406/geo.1948.12225

Krijgsman, W., Hilgen, F.J., Ral., Sierro, F.J., Wilson, D.S., 1999. Chronology, causes and progression of the Messinian salinity crisis. Nature 400, 652-655.

Lacombe, O. et Jolivet, L., 2005. Structural and kinematic relationships between Corsica and the Pyrenees-Provence domain at the time of the Pyrenean orogeny. Tectonics, 24: $20 \mathrm{p}$.

Leenhardt O., Pierrot S., Rebuffati A., Sabatier H., 1969. Etude sismique de la zone de Planier (Bouches du Rhône) Revue de l'Institut Français du Pétrole, XXIV, 11, p. 1261-1287.

Lefebvre, D. 1980. Evolution morphologique et structurale du Golfe du Lion. Essai de traitement statistique des données, Thèse, Université de Paris 6, Paris, 163 pp.

Lofi, J., 2002. La Crise de Salinité Messinienne : Incidences directes et différées sur l'évolution sédimentaire de la marge du Golfe du Lion, These de Troisième Cycle, University of Lille I, 285pp.

Lofi J., Rabineau M., Gorini C., Berné S., Clauzon G., De Clarens P., Moutain G.S., Ryan W.B.F., Steckler M.S. and Fouchet C., 2003. Plio-Quaternary prograding clinoform wedges of the Western Gulf of Lions continental margin (NW Mediterranean) after the Messinian Salinity Crisis, Marine Geology 198 (3-4), pp. 289-317. 
Lofi, J., Gorini, C., Berne, S., Clauzon, G., Dos Reis, A.T., Ryan, W.B.F., Steckler, M., 2005. Paleoenvironmental changes and erosional processes on the western Gulf of Lions during the Messinian Salinity Crisis. Marine Geology 217 (1-2), 1-30.

Lofi, J., Berné, S., 2008. Evidence for pre-Messinian submarine canyons on the Gulf of Lions slope (Western Mediterranean). Marine and Petroleum Geology 25 (8), 804e817.

Lofi J, Déverchère J., Gaullier V., Gillet H., Gorini C., Guennoc P., Loncke L., Maillard A., Sage F., Thinon I., 2011. Seismic Atlas of the "Messinian Salinity Crisis" Markers in the Mediterranean and Black Seas. Commission for the Geological Map of the World/ Mémoires de la Société Géologique de France, n.s., t.179, 72p.

Loget, N., Van den Driessche, J., Davy, P., 2005. How did the Messinian Salinity Crisis end? Terra Nova 17.

Maufret, A., Gorini, C., 1996. Structural style of the Camargue area and western Provençal basin (Southern France), geodynamic consequences. Tectonics 15, 356-375.

Meniscus X., 2012. Compte-rendu de la plongée du 7 mai 2012 à -223m à Port Miou, Cassis, France. 8 p. http://cnps.plongeesouterraine.org

McKenzie J.A., 1999. From desert to deluge in the Mediterranean.- Nature, 400, 613-614.

Mitchum, R.M. Jr., Vail, P.R., 1977. Seismic stratigraphy and global changes of sea-level, part 7. Stratigraphic interpretation of seismic reflection patterns in depositional sequences. In: Payton, C.E. (Ed.), Seismic Stratigraphy Applications to Hydrocarbon Exploration. Memoir of the American Association of Petroleum Geologists, Tulsa, 26, pp. 135-144.

Mocochain L., Clauzon G. \& Bigot J.-Y., 2006a. Réponses de l'endokarst ardéchois aux variations eustatiques générées par la crise messinienne. Bull. Soc. géol. France, t. 177, 1, p. 27-36.

Mocochain L., Clauzon G., Bigot J.-Y., Brunet P., 2006 b. Geodynamic evolution of the peri mediterranean karst during the Messinian and the Pliocene: evidence from the Ardèche and the Rhône Valley systems canyons, Southern France. Sedimentary Geology, 188-189, 219233.

Mocochain L., Bigot J.-Y., Clauzon G., Faverjon M., \& Brunet Ph., 2006c. La grotte de SaintMarcel (Ardèche) : un référentiel pour l'évolution des endokarsts méditerranéens depuis 6 Ma. Karstologia, 48, pp. 33-50.

Mocochain L., Audra P., Clauzon G., Bellier O., Parize O., Monteil P., Bigot J.-Y., 2009. The Messinian Salinity Crisis manifestations on landscape geodynamic: karst surface, river 
piracies, and cave levels: Example of the Lower Ardèche River (Rhône Mid-Valley). Geomorphology, 106, 46-61.

Mocochain L., Audra P. \& Bigot J.-Y., 2011. Base level rise and per ascensum model of speleogenesis (PAMS). Interpretation of deep phreatic karsts, vauclusian springs and chimney-shafts. Bull. Soc. géol. France, t. 182, no 2, p.87-93.

Montigny R., Edel J.-B. \& Thuizat R. 1981. Oligo-Miocene rotation of Sardinia: K-Ar ages and paleomagnetic data of Tertiary volcanics. - Earth Planet. Sci. Lett., 54, 269-271.

Nesteroff, W.D., 1973. The sedimentary history of the Mediterranean area during the Neogene. In: Ryan, W.B.F., Hsü, K.J., et al. (Eds.), Initial Reports of Deep Sea Drilling Project, vol. 13. U.S. Government Printing Office, Washington, pp. 1257-1261.

Nury, D. 1988. L'Oligocène de Provence méridionale: stratigraphie, dynamique sédimentaire, reconstitutions paléogéographiques. Thèse d'Etat, Univ. De Provence: 411.

Oudet, J., 2008. Etude terre-mer de la transition syn-rift/post-rift sur les marges de l'océan Liguro-Provençal: apports de la modélisation 3D et de la chronostratigraphie intégrée. Thèse de l'Université de Provence, p. 288.

Oudet, J., Münch, P., Borgomano, J., Quillévéré, F., Melinte-Dobrinescu, M., Demory, F., Viseur, S., Cornée, J.J., 2010a. Land and sea study of the Northeastern Golfe du Lion rifted margin: the Oligocene-Miocene of southern Provence (Nerthe area, SE France). Bulletin de la Société Géologique de France 181 (6), 591e607. doi:10.2113/gssgfbull.181.6.591.

Peres J.M. et Picard J., 1964. Nouveau manuel de bionomie benthique de la Méditerranée. Rec. Trav. Stat. Mar. Endoume, (47), 317 : 1-13. 9 fig.

Rabineau, M., Berné, S., Ledrezen, E., Lericolais, G., Marsset, T., Rotunno, M., 1998. 3D architecture of lowstand and transgressive Quaternary sand bodies on the outer shelf of the Gulf of Lion, France. Marine and Petroleum Geology 15, 439-452.

Rabineau M., Berné S., Aslanian D, Olivet J-L., Joseph P., Guillocheau F, Bourillet J-F, Ledrezen E, Granjeon D., 2005. Sedimentary sequences in the Gulf of Lion: A record of 100,000 years climatic cycles, Marine and Petroleum Geology 22, 775-804

Rizzini, A., Vezzani, F., Cococcetta, V., Milad, G., 1978. Stratigraphy and sedimentation of a Neogen-Quaternary section in the Nile delta aera (A.R.E.). Mar. Geol. 27, 327-348.

Rollet, N., 1999. Structure profonde et dynamique du Bassin Ligure et de ses marges. Thèse de Doctorat, Univ. P. et M. Curie, Paris, 324 p. 
Rouire J., L’Homer A., J.-J.Blanc, 1979 Carte géologique de la France à 1/250000 Feuille Marseille - BRGM.

Rouire J., and J.-J.Blanc, 1979. Feuille Marseille et notice explicative de la feuille Marseille à $1 / 250000$ - BRGM.

Roure F., Monti S. et Le Lann A., 1978. "Campagne Estocade", submersible Cyana, 4-26 août 1976. Pub. C.N.E.X.O., Résultats des campagnes à la mer, 14, 95 p.

Roure F. and Colletta B., 1996. Cenozoic inversion structures in the foreland of the Pyrenees and Alps. In Ziegler P. and Horvath F., eds., PeriTethys Mem. 2, Mus. Hist. Nat., Paris, 173210.,

Ryan, W.B.F., 1976. Quantitative evaluation of the depth of the Western Mediterranean before, during and after the Messinian salinity crisis. Sedimentology 23, 791-813

Ryan, W.B.F., Cita, M.B., 1978. The nature and distribution of Messinian erosional surfaces: indicators of several kilometers deep Mediterranean in the Miocene. Marine Geology 27, 193-230.

Sage F., Beslier M.-O., Thinon I., Larroque C., Dessa J.-X., Migeon S., Angelier J., Guennoc P., Schreiber D., Michaud F., Stephan J.-F., Sonnette L., 2011. Structure and evolution of a passive margin in a compressive environment: Example of the south-western Alps-Ligurian basin junction during the Cenozoic. Marine and Petroleum Geology 28, 1263-1282.

Séranne, M., Benedicto-Esteban, A., Labaum, P., Truffert, C.,Pascal, G., 1995 -. Structural style and evolution of the Gulf of Lion Oligo-Miocene rifting: role of the Pyrenean orogeny. Marine and Petroleum Geology 12(8): 809-820.

Séranne, M., 1999. The Gulf of Lion continental margin (NW Mediterranean) revisited by IBS: an overview. In: L.J. B. Durant, F. Horvath and M. Séranne. (Editor), The Mediterranean Basins: Tertiary Extension within the Alpine Orogen. London: Geological Society, 15-36.

Toutin-Morin and Bonijoly D., 1992. Structuration des basins de Provence orientale à la fin de l'ère primaire: Cuadernos de Geologica Iberica, V. 16, p.59-74.

Toutin-Morin N. and Bonijoly D. et al. 1994. Notice explicative: Carte géologique de la France à 1/50000, feuille Fréjus-Canne, $n^{\circ} 1024$. Bureau de Recherche Géologique et Minière, Orléans.

Villeger, M., Andrieux, J., 1987. Phases tectoniques post-Eocènes et structuration polyphasée du panneau de couverture nord provençal (Alpes externes méridionales). Bull. Soc. geol. Fr. 8, 147-156. 


\section{FIGURES \& TABLES CAPTIONS}

Figure 1: 1A: Offshore: submarine canyons of the continental shelf of Gulf of Lions, Provence and Ligure margins (Source: SHOM, IFREMER); onshore: Present-day drainage network (in black), Messinian incisions (in yellow) and Pliocene rias of Southeast France (in blue; modified from Mocochain et al., 2011). 1B: Topographic map of Southern Provence and bathymetric map of the Provence continental shelf. The main karst area and hydrographic networks are reported. (Source: IGN, SHOM, IFREMER).

Figure 2: 2A: Onshore-offshore structural map of Southeast France with distribution of the Hercynian basement, tectonic structures of Pyrenean and Alpine compressions, and Permian and Oligocene basins. FNP: Nord-Pyrenean fault; FC: Cévennes fault; FdN: Nîmes fault; FSC: Salon-Cavaillon fault; FA: Aix fault; FMD: Middle Durance fault. Modified, from Lacombe and Jolivet (2005), Séranne (1995). 2B: Location of the seismic profiles and cores and simplified 1:250000 geological map of Southern Provence (modified from Rouire et al., 1979. Heavy lines correspond to the illustrations cited in the text.

Figure 3: Core sections of newly collected sea-bottom rock samples. (a): Bioclastic packstone. Age: Oligo-Miocene, sample CAS09-CR17, (b): Foraminiferal grainstone. Age: probable Cenomanian, sample CAS09-CR57, (c): Foraminiferal grainstone. Age: probable Cenomanian, sample CAS09-C65, (d): Phyllad, Age: Paleozoic, sample CAS09CR60, (e): Siliceous spiculite. Age: probabble Aptian, sample CAS09-CR40, (f): Cimented conglomerate with peloidal grainstone and shells. Age: Pliocene, sample CAS09-CR74.

TABLEAU 1: Description of rocks samples from CASSEIS 2009 cruise (coordinates in WGS84; CNEXO-VILLE rock corer, in blue) and Froget (1974) samples (in green). For each sample, the name, WGS84 position (lat/lon/bathy), and lithology are indicated. Ages are mentioned when dating were possible.

Figure 4: Definition of the seismostratigraphic units on the basis of their seismic attributes (reflector continuity, amplitude and frequency) and the nature of their bounding surfaces. Interpreted ages are reported for each unit.

Figure 5: Seismic image and interpretation of the CAS09-spk06 VHR seismic profile, showing the structure of the shelf at north of Cassidaigne canyon (see location on Figure 2). Seismic units colors are defined in Figure 4.

Figure 6: HR seismic image and interpretation of profile cas09gi-36 located in the Central area, crossing Marion-03 profile (see location on Figure 2). Seismic units colors are defined in Figure 4.

Figure 7: a: Interpretation of profile CAS09-gi31, located on the eastern flank of the Cassidaigne canyon, oriented SSWNNE. b: Interpretation of profile CAS2011-53 oriented W-E (see location on Figure 2). Seismic units colors are defined in Figure 4.

Figure 8: a: Coastal outcrops and interpretation of the CAS09-spk8 VHR profile, oriented W-E and located in the Cassis bay. b: VHR seismic image and interpretation of profile CAS2011-89 located in the Eastern area, close to the coast and Cassis (see location on Figure 2). Seismic units colors are defined in Figure 4.

Figure 9: a: interpretation of ms108-63 VHR seismic profile located in the southern part of the Marseilles basin (see location on Figure 2). b: interpretation of ms108-85 VHR seismic profile located at south of the Frioul islands (see location on Figure 2). Seismic units colors are defined in Figure 4.

Figure 10: VHR Seismic image and interpretation of profile ms108-17 located in the Western area (see location in Figure 2). Seismic units colors are defined in Figure 4.

Figure 11: a: Interpretation of the HR seismic profile LM122 situated on the eastern flank of Cassidaigne canyon (see location on Fig. 2); b: Interpretation of the HR seismic profile LM108 across the Cassidaigne canyon (see location on Fig. 2). c: Interpretation of profile Marion- 03 corresponding to a $120 \mathrm{~km}$ W-E LR seismic profile extending from the offshore Rhône valley to the Riou area (see location on Fig. 2), on the western edge of Cassidaigne canyon (Modified from Lofi, 2005). Seismic units colors are defined in Figure 4.

Figure 12: a: Interpretation of the VHR seismic profile CAS2011-75 situated on the Eastern area (see location on Fig. 2); b: Interpretation of HR profile cas09gi-46 (see location on Fig. 2); c: Interpretation of HR profile cas09gi-02 corresponding to a S-N seismic line extending from the slope to the shelf, near the Bandol coastline (see location on Fig. 2). Seismic units colors are defined in Figure 4.

Figure 13: Linedrawing of seismic profiles Marion-03, LM 108, LM 118, h091m104, h091m108, CAS2011-gi10 across the Cassidaigne canyon. MNT of the seabed depth built from the seismic interpretation (in $\mathrm{m}$ ). Seismic units colors are defined in Figure 4. 
Figure 14: Geological map from onshore Southern Provence (modified after the BRGM Geological Map of Marseille 1/ 250000) and offshore Provence continental shelf (this study). Plio-Quaternary deposits (Unit 6) are mapped when its two-way time thickness is higher than $100 \mathrm{~ms}$.

Figure 15: Land-to-sea cross sections of the Provence Margin. A: N-S cross section from Beausset unit onland to the Bandol canyon and the continental shelf break offshore. B: N-S cross section from Huveaune valley onland to Riou islands and continental shelf break. C: N-S cross section from Nerthe massif onland to offshore Marseille basin and the continental shelf break.

Figure 16: A: Depth-map (m) of the Base Plio-Quaternary Surface (according to hypothesis 1 in the Bandol canyon) offshore Provence. B: Depth map $(\mathrm{m})$ of the Base Plio-Quaternary in the Cassidaigne and Bandol canyons area, according to hypothesis 1; C: Depth map (m) of the Base Plio-Quaternary in the Cassidaigne and Bandol canyons area, according to hypothesis 2 .

Figure 17: A: High resolution bathymetric map of present-day Cassidaigne canyon (C) IFREMER; ESROV 2010 survey); B: Geomorphological map deduced to interpretation of the high resolution bathymetric map.

Figure 18: Messinian erosion of Cassidaigne and Bandol canyons and Plio-Quaternary infills: A: Location of PlioPleistocene deposits within the Messinian incision superimposed to the 3D surface of base Plio-Quaternary deposits. B: Thickness of Plio-Pleistocene deposits within Bandol and Cassidaigne canyons superimposed to the high resolution bathymetric map according to hypothesis 1 .

Figure 19: Messinian hydrographic network display on the base Plio-Quaternary surface of Provence shelf. Dashed lines: if the hydrographic network is of karstic nature; full lines if it is subaerial. Hypothetical Messinian springs are indicated in Planier and Cassidaigne canyons heads by red circles. Present-day rivers and massifs onland are also drawned. 
ACCEPTED MANUSCRIPT

\begin{tabular}{|c|c|c|c|c|c|}
\hline CORE NAME & $\begin{array}{c}\text { X (lat. } \\
\text { WGS84) }\end{array}$ & $\begin{array}{l}\text { Y (lon. } \\
\text { WGS84) }\end{array}$ & $\mathrm{Z}(\mathrm{m})$ & CORE DESCRIPTION & AGE \\
\hline CAS09_CR01 & $43^{\circ} 17,972$ & $5^{\circ} 20,276$ & 39,3 & Corraline mud & Pleistocene \\
\hline CAS09_CR01b & $43^{\circ} 17,974$ & $5^{\circ} 20,302$ & 38,9 & $\begin{array}{l}\text { Mud with Cladocora and rock } \\
\text { fragments }\end{array}$ & Pleistocene \\
\hline CAS09_CR02 & $43^{\circ} 18,112$ & $5^{\circ} 20,158$ & 40,4 & Fine-grained sandstone & Pleistocene \\
\hline CAS09_CR03 & $43^{\circ} 18,426$ & $5^{\circ} 19,865$ & 42,5 & $\begin{array}{l}\text { Mud, argilaceous medium to coarse- } \\
\text { grained sandstone }\end{array}$ & Pleistocene \\
\hline CAS09_CR03b & $43^{\circ} 18,432$ & $5^{\circ} 19,868$ & 45 & $\begin{array}{l}\text { Bioclastic mud (Bryozoaires, } \\
\text { Molluskals) }\end{array}$ & Pleistocene \\
\hline CAS09_CR04 & $43^{\circ} 18,563$ & $5^{\circ} 19,737$ & 49 & Mud with rock fragments (obsidienne?) & Pleistocene \\
\hline CAS09_CR05 & $43^{\circ} 18,728$ & $5^{\circ} 19,593$ & 55 & $\begin{array}{l}\text { Mud, rhodolithe, ferruginized } \\
\text { conglomerate }\end{array}$ & Pleistocene \\
\hline CAS09_CR06 & $43^{\circ} 19,904$ & $5^{\circ} 18,474$ & 59,2 & $\begin{array}{l}\text { Peloidal packstone with fresh-water } \\
\text { gastropod molds (lacustrine limestone) }\end{array}$ & $\begin{array}{l}\text { Oligocene } \\
\text { (Rupelian) }\end{array}$ \\
\hline CAS09_CR06b & $43^{\circ} 19,885$ & $5^{\circ} 18,493$ & 59 & $\begin{array}{l}\text { Mud with shell fragments, lacustrine } \\
\text { gastropode limestone, siltite }\end{array}$ & undetermined \\
\hline CAS09_CR07 & $43^{\circ} 20,244$ & $5^{\circ} 18,113$ & 55,2 & $\begin{array}{c}\text { Medium-to-coarse-grained sandstone } \\
\text { with angular quartz grain, calcite sparry } \\
\text { cement }\end{array}$ & undetermined \\
\hline CAS09_CR08 & $43^{\circ} 20,412$ & $5^{\circ} 17,921$ & 52,2 & mud & Pleistocene \\
\hline CAS09_CR09 & $43^{\circ} 20,652$ & $5^{\circ} 17,695$ & 42,7 & Argilaceous sand with shell fragments & Pleistocene \\
\hline CAS09_CR10 & $43^{\circ} 20,539$ & $5^{\circ} 17,417$ & 51,2 & Argilaceous sand with pebbles & Pleistocene \\
\hline CAS09_CR11 & $43^{\circ} 20,438$ & $5^{\circ} 17,167$ & 44,2 & Argilaceous sand with shell fragments & Pleistocene \\
\hline CAS09_CR12 & $43^{\circ} 20,272$ & $5^{\circ} 16,827$ & 47,5 & Argilaceous sand & undetermined \\
\hline CAS09_CR12bis & $43^{\circ} 20,268$ & $5^{\circ} 16,82$ & 47,5 & coral, silt & Undetermined \\
\hline CAS09_CR13 & $43^{\circ} 20,095$ & $5^{\circ} 16,411$ & 52,5 & marl & Undetermined \\
\hline CAS09_CR14 & $43^{\circ} 19,962$ & $5^{\circ} 16,138$ & 50,5 & sands, corraline crust, serpules & Undetermined \\
\hline CAS09_CR14b & $43^{\circ} 19,958$ & $5^{\circ} 16,135$ & 51 & $\begin{array}{l}\text { Marls and sands, corraline crust, } \\
\text { serpules }\end{array}$ & Undetermined \\
\hline CAS09_CR15 & $43^{\circ} 19,926$ & $5^{\circ} 16,061$ & 51,5 & Marls and sands & Undetermined \\
\hline CAS09_CR16 & $43^{\circ} 19,594$ & $5^{\circ} 15,343$ & 62 & Marls & Undetermined \\
\hline CAS09_CR17 & $43^{\circ} 19,147$ & $5^{\circ} 14,2$ & 68 & $\begin{array}{c}\text { Packstone with Foraminifers } \\
\text { (miliolids), Scleractinian, Mollusks and } \\
\text { Echinoderms }\end{array}$ & Lower Miocene? \\
\hline CAS09_CR18 & $43^{\circ} 19,555$ & $5^{\circ} 14,654$ & 54,5 & $\begin{array}{l}\text { Carbonate mudstone with ostracods, } \\
\text { gastropods, coated grains, } \\
\text { circumgranular cracks (palustrine } \\
\text { limestone) }\end{array}$ & $\begin{array}{l}\text { Oligocene } \\
\text { (Rupelian) }\end{array}$ \\
\hline CAS09_CR18b & $43^{\circ} 19,558$ & $5^{\circ} 14,671$ & 53 & & Undetermined \\
\hline CAS09_CR19 & $43^{\circ} 19,33$ & $5^{\circ} 14,315$ & 60,7 & $\begin{array}{l}\text { Carbonate breccia with micritic } \\
\text { elements (pedogenic breccia?) }\end{array}$ & $\begin{array}{l}\text { Oligocene } \\
\text { (Rupelian) }\end{array}$ \\
\hline CAS09_CR20 & $43^{\circ} 19,263$ & $5^{\circ} 10,021$ & 34,5 & & Undetermined \\
\hline CAS09_CR21 & $43^{\circ} 19,383$ & $5^{\circ} 10,535$ & 20,5 & $\begin{array}{c}\text { Conglomerate with rounded pebbles } \\
\text { and sparry cements }\end{array}$ & Undetermined \\
\hline CAS09_CR22 & $43^{\circ} 19,111$ & $5^{\circ} 10,989$ & 40,7 & Mud with rock fragments & Pleistocene \\
\hline CAS09_CR22b & $43^{\circ} 19,109$ & $5^{\circ} 11,989$ & 40,2 & Mud with shell fragments & Pleistocene \\
\hline CAS09_CR23 & $43^{\circ} 19,091$ & $5^{\circ} 10,676$ & 38 & Mud with shell fragments & Pleistocene \\
\hline CAS09_CR24 & $43^{\circ} 19,079$ & $5^{\circ} 9,938$ & 25 & $\begin{array}{l}\text { Mud, red algal, Bryozoaires, Molluskal, } \\
\text { serpules, cement }\end{array}$ & Undetermined \\
\hline CAS09_CR24b & $43^{\circ} 19,078$ & $5^{\circ} 9,951$ & 31,7 & red algal and oyster limestone & Undetermined \\
\hline CAS09_CR25 & $43^{\circ} 19,081$ & $5^{\circ} 9,819$ & 24,2 & Recrystallized (calcitized) coral & Undetermined \\
\hline CAS09_CR26 & $43^{\circ} 18,692$ & $5^{\circ} 9,492$ & 29 & Argilaceous carbonate sands & Undetermined \\
\hline CAS09_CR26b & $43^{\circ} 18,701$ & $5^{\circ} 9,489$ & 26,5 & $\begin{array}{c}\text { red algual and shell fragments showing } \\
\text { ferrugenization }\end{array}$ & undetermined \\
\hline CAS09_CR27 & $43^{\circ} 18,684$ & $5^{\circ} 8,363$ & 27 & red algual and shell fragments & Pleistocene \\
\hline CAS09_CR27b & $43^{\circ} 18,701$ & $5^{\circ} 7,956$ & 33,5 & red algual & Pleistocene \\
\hline CAS09_CR28 & $43^{\circ} 18,704$ & $5^{\circ} 7,477$ & 40,7 & Bioclastic mud & Pleistocene \\
\hline
\end{tabular}




\section{ACCEPTED MANUSCRIPT}

\begin{tabular}{|c|c|c|c|c|c|}
\hline CAS09_CR29 & $43^{\circ} 17,98$ & $5^{\circ} 8,386$ & 54,2 & $\begin{array}{c}\text { Fine-to-medium-grained sandstone } \\
\text { with angular quartz grain, calcite sparry } \\
\text { cement }\end{array}$ & Undetermined \\
\hline CAS09_CR29b & $43^{\circ} 17,975$ & $5^{\circ} 8,392$ & 54,7 & $\begin{array}{l}\text { Medium-grained sandstone, limestone } \\
\text { pebbles with perforations }\end{array}$ & Undetermined \\
\hline CAS09_CR30 & $43^{\circ} 17,968$ & $5^{\circ} 8,848$ & 57,5 & Bioclastic muds, algual fragments & Pleistocene \\
\hline CAS09_CR30b & $43^{\circ} 17,971$ & $5^{\circ} 8,815$ & 53,7 & Bioclastic muds, Spondylle fragments & Undetermined \\
\hline CAS09_CR31 & $43^{\circ} 17,982$ & $5^{\circ} 7,818$ & 53 & $\begin{array}{l}\text { Medium-grained sandstone with } \\
\text { angular quartz grain, calcite sparry } \\
\text { cement, miliolids }\end{array}$ & undetermined \\
\hline CAS09_CR32 & $43^{\circ} 17,996$ & $5^{\circ} 6,658$ & 62,7 & algual mud & Pleistocene \\
\hline CAS09_CR33 & $43^{\circ} 16,716$ & $5^{\circ} 8,488$ & 68,2 & $\begin{array}{l}\text { Medium-grained sandstone with } \\
\text { angular quartz grain, calcite sparry } \\
\text { cement, miliolids }\end{array}$ & Undetermined \\
\hline CAS09_CR33b & $43^{\circ} 16,716$ & $5^{\circ} 8,488$ & 68,2 & red algual sands and fine limestone & Undetermined \\
\hline CAS09_CR34 & $43^{\circ} 17,888$ & $5^{\circ} 11,029$ & 54,5 & algual sand & Pleistocene \\
\hline CAS09_CR35 & $43^{\circ} 15,978$ & $5^{\circ} 10,263$ & 71,7 & Quartzous calcarenite & Undetermined \\
\hline CAS09_CR36 & $43^{\circ} 15,552$ & $5^{\circ} 9,496$ & 73,5 & $\begin{array}{l}\text { Quartzous calcarenite with benthic } \\
\text { forams }\end{array}$ & Undetermined \\
\hline CAS09_CR37 & $43^{\circ} 15,187$ & $5^{\circ} 8,835$ & 83,5 & $\begin{array}{l}\text { Quartzous calcarenite with benthic } \\
\text { forams, echinoderms (echinoids, } \\
\text { holothurians), leached/recrystalized } \\
\text { mollusks. }\end{array}$ & Undetermined \\
\hline CAS09_CR38 & $43^{\circ} 14,883$ & $5^{\circ} 8,265$ & 88,2 & $\begin{array}{l}\text { 38a: Fine-grained glauconitic sandstone } \\
\text { with sparry cements; } 38 \mathrm{~b} \text { : } \\
\text { Recrystallized (calcitized) coral }\end{array}$ & Undetermined \\
\hline CAS09_CR39 & $43^{\circ} 14,67$ & $5^{\circ} 7,873$ & 88,2 & $\begin{array}{c}\text { Fine-grained glauconitic sandstone with } \\
\text { sparry cements. }\end{array}$ & Undetermined \\
\hline CAS09_CR39b & $43^{\circ} 14,668$ & $5^{\circ} 7,869$ & 88 & $\begin{array}{l}\text { 39b: Laminated silty clay with forams; } \\
\text { 39e, f, g: strongly compacted sandstone } \\
\text { with calcitic sparry cement. }\end{array}$ & undetermined \\
\hline CAS09_CR40 & $43^{\circ} 3,825$ & $5^{\circ} 38,785$ & 97 & Phyllad & Paleozoic \\
\hline CAS09_CR41 & $43^{\circ} 3,325$ & $5^{\circ} 38,277$ & 93,2 & Phyllad & Paleozoic \\
\hline CAS09_CR42 & $43^{\circ} 3,503$ & $5^{\circ} 36,973$ & 112 & Phyllad & Paleozoic \\
\hline CAS09_CR43 & $43^{\circ} 3,883$ & $5^{\circ} 35,213$ & 127 & Phyllad & Paleozoic \\
\hline CAS09_CR44 & $43^{\circ} 7,9391$ & $5^{\circ} 27,427$ & 320 & Mud & Pleistocene \\
\hline CAS09_CR45 & $43^{\circ} 7,976$ & $5^{\circ} 27,343$ & 290 & Mud & Pleistocene \\
\hline CAS09_CR46 & $43^{\circ} 7,986$ & $5^{\circ} 27,216$ & 246 & Mud & Pleistocene \\
\hline CAS09_CR47 & $43^{\circ} 8,034$ & $5^{\circ} 26,987$ & 148 & Mud & Pleistocene \\
\hline CAS09_CR48 & $43^{\circ} 7,243$ & $5^{\circ} 31$ & 281 & Shell carbonate sand & Undetermined \\
\hline CAS09_CR49 & $43^{\circ} 7,344$ & $5^{\circ} 31,369$ & 123,6 & no sample & Undetermined \\
\hline CAS09_CR49bis & $43^{\circ} 7,343$ & $5^{\circ} 31,352$ & 123,2 & $\begin{array}{l}\text { Sparitic limestone with limestone } \\
\text { ferruginized pebbles }\end{array}$ & Undetermined \\
\hline CAS09_CR50 & $43^{\circ} 8,067$ & $5^{\circ} 32,433$ & 40 & Red algual sands & Pleistocene \\
\hline CAS09_CR51 & $43^{\circ} 7,821$ & $5^{\circ} 32,104$ & 83,2 & $\begin{array}{l}\text { Red algual, molluskal, bryozoaires and } \\
\text { polypial carbonate sands }\end{array}$ & Undetermined \\
\hline CAS09_CR52 & $43^{\circ} 8,194$ & $5^{\circ} 32,515$ & 37,2 & $\begin{array}{l}\text { Red algual, molluskal, bryozoaires and } \\
\text { polypial carbonate sands }\end{array}$ & Undetermined \\
\hline CAS09_CR53 & $43^{\circ} 8,307$ & $5^{\circ} 32,698$ & 45,6 & & Undetermined \\
\hline CAS09_CR54 & $43^{\circ} 8,834$ & $5^{\circ} 32,424$ & 70 & Bivalve carbonate sands & Undetermined \\
\hline CAS09_CR55 & $43^{\circ} 8,83$ & $5^{\circ} 32,372$ & 75 & Bivalve carbonate sands & Undetermined \\
\hline CAS09_CR56 & $43^{\circ} 9,263$ & $5^{\circ} 32,256$ & 80,4 & & Undetermined \\
\hline CAS09_CR57 & $43^{\circ} 11,823$ & $5^{\circ} 31,752$ & 48 & Sand & undetermined \\
\hline CAS09_CR57bis & $43^{\circ} 11,785$ & $5^{\circ} 31,762$ & 51 & $\begin{array}{c}\text { Echinoderm, Red algal and } \\
\text { foraminiferal (Hedbergella, Rotalipora) } \\
\text { glauconitic packstone. }\end{array}$ & Cenomanian \\
\hline CAS09_CR58 & $43^{\circ} 11,82$ & $5^{\circ} 32,204$ & 48 & Sand and mud & Undetermined \\
\hline CAS09_CR59 & $43^{\circ} 10,498$ & $5^{\circ} 32,331$ & 78 & Sand & Undetermined \\
\hline CAS09_CR59bis & $43^{\circ} 10,496$ & $5^{\circ} 32,297$ & 81 & Sand & Undetermined \\
\hline CAS09_CR60 & $43^{\circ} 10,485$ & $5^{\circ} 32,208$ & 80 & Siliceous spiculite. & Aptian-Albian \\
\hline
\end{tabular}




\section{ACCEPTED MANUSCRIPT}

\begin{tabular}{|c|c|c|c|c|c|}
\hline CAS09_CR61 & $43^{\circ} 10,364$ & $5^{\circ} 31,889$ & 81 & Sand with shell fragments & Undetermined \\
\hline CAS09_CR62 & $43^{\circ} 10,377$ & $5^{\circ} 31,897$ & 80 & Qz calcarenite with sponge spicules. & Undetermined \\
\hline CAS09_CR63 & $43^{\circ} 10,351$ & $5^{\circ} 31,837$ & 82 & $\begin{array}{c}\text { red algal and gastropodes carbonate } \\
\text { sands }\end{array}$ & Undetermined \\
\hline CAS09_CR64 & $43^{\circ} 10,321$ & $5^{\circ} 31,664$ & 85 & Quartzite & Undetermined \\
\hline CAS09_CR65 & $43^{\circ} 10,125$ & $5^{\circ} 32,207$ & 79 & $\begin{array}{c}\text { Foraminiferal peloidal Packstone } \\
\text { Grainstone with orbitolinids and } \\
\text { miliolids }\end{array}$ & Cenomanian? \\
\hline CAS09_CR65bis & $43^{\circ} 10,142$ & $5^{\circ} 32,177$ & 79 & Calcimicrobe mudstone/bindstone & Undetermined \\
\hline CAS09_CR66 & $43^{\circ} 10,16$ & $5^{\circ} 32,286$ & 76 & & Undetermined \\
\hline CAS09_CR67 & $43^{\circ} 10,214$ & $5^{\circ} 32,403$ & 69,6 & argilaceous carbonate sands & Undetermined \\
\hline CAS09_CR67bis & $43^{\circ} 10,251$ & $5^{\circ} 32,365$ & 74 & & undetermined \\
\hline CAS09_CR68 & $43^{\circ} 9,846$ & $5^{\circ} 32,066$ & 85 & red algal-molluskal sands and echinidés & Undetermined \\
\hline CAS09_CR69 & $43^{\circ} 9,363$ & $5^{\circ} 32,264$ & 80 & & Undetermined \\
\hline CAS09_CR70 & $43^{\circ} 9,004$ & $5^{\circ} 37,32$ & 67 & $\begin{array}{c}\text { Qz calcarenite with sponge spicula, } \\
\text { forams. }\end{array}$ & Undetermined \\
\hline CAS09_CR71 & $43^{\circ} 9,256$ & $5^{\circ} 38,233$ & 68 & Fine sands & Undetermined \\
\hline CAS09_CR72 & $43^{\circ} 10$ & $5^{\circ} 39,906$ & 43,2 & Sand with shell fragments & Undetermined \\
\hline CAS09_CR73 & $43^{\circ} 8,109$ & $5^{\circ} 39,428$ & 88 & Sand & Undetermined \\
\hline CAS09_CR74 & $43^{\circ} 6,829$ & $5^{\circ} 43,297$ & 59 & $\begin{array}{l}\text { Conglomerate with tighlty cemented } \\
\text { glauconitic sandstone matrix and } \\
\text { rounded limestone pebbles }\end{array}$ & undetermined \\
\hline CAS09_CR74bis & $43^{\circ} 6,829$ & $5^{\circ} 43,297$ & 59 & $\begin{array}{l}\text { Conglomerate with tighlty cemented } \\
\text { glauconitic sandstone matrix and } \\
\text { rounded limestone pebbles }\end{array}$ & Pliocene? \\
\hline
\end{tabular}

\begin{tabular}{|c|c|c|c|c|c|}
\hline C3 & $43^{\circ} 08,160$ & $05^{\circ} 25,490$ & 90 & & $\begin{array}{l}\text { Würm IV- } \\
\text { Holocene }\end{array}$ \\
\hline C4 & $43^{\circ} 04,285$ & $05^{\circ} 21,760$ & 190 & $y$ & Würm III-IV \\
\hline $\begin{array}{l}\text { R48-R84-R88- } \\
\text { R139-R180 }\end{array}$ & $43^{\circ} 08,150$ & $05^{\circ} 27,600$ & $250-500$ & argilaceous carbonate sands & Pliocene \\
\hline R86 & $43^{\circ} 08,150$ & $05^{\circ} 27,600$ & $150-200$ & red algal calcarenite and calcirudite & Pliocene \\
\hline R109-R110 & $43^{\circ} 06,580$ & $05^{\circ} 32,720$ & $150-201$ & red algal calcarenite and calcirudite & Pliocene \\
\hline R15 & $43^{\circ} 01,180$ & $05^{\circ} 30,900$ & 270 & Halimeda limestone & $\begin{array}{l}\text { Upper Miocene- } \\
\text { Pliocene? }\end{array}$ \\
\hline R16 & $43^{\circ} 01,180$ & $05^{\circ} 30,900$ & 250 & Halimeda limestone & $\begin{array}{l}\text { Upper Miocene- } \\
\text { Pliocene? }\end{array}$ \\
\hline R165 & $43^{\circ} 06,315$ & $05^{\circ} 15,450$ & 275 & foraminiferal-molluskal calcarenite & Pleistocene \\
\hline R171 & $43^{\circ} 06,840$ & $05^{\circ} 15,450$ & 200 & foraminiferal-molluskal calcarenite & Pleistocene \\
\hline R181 & $43^{\circ} 06,840$ & $05^{\circ} 13,450$ & & conglomerate & Pleistocene \\
\hline R17 & $43^{\circ} 03,03$ & $05^{\circ} 24,360$ & 170 & red algal calcarenite & Pleistocene \\
\hline R18 & $43^{\circ} 03,03$ & $05^{\circ} 24,360$ & 190 & red algal calcarenite & Pleistocene \\
\hline R20 & $43^{\circ} 04,255$ & $05^{\circ} 30,220$ & $30-340$ & & Pliocene \\
\hline R51 & $43^{\circ} 03,03$ & $05^{\circ} 24,360$ & $180-200$ & red algal calcarenite & Pleistocene \\
\hline R47 & $43^{\circ} 05,920$ & $05^{\circ} 27,270$ & 200 & molluskal-algal calcarenite & Pleistocene \\
\hline a1 & $43^{\circ} 07,100$ & $05^{\circ} 26,200$ & 150 & Marls and glauconitic limestones & Aptian \\
\hline a2 & $43^{\circ} 05,400$ & $05^{\circ} 25,800$ & & Marls and glauconitic limestones & Aptian \\
\hline a3 & $43^{\circ} 05,300$ & $05^{\circ} 26,100$ & & Marls and glauconitic limestones & Aptian \\
\hline a4 & $43^{\circ} 08,150$ & $05^{\circ} 31,400$ & 150 & $\begin{array}{l}\text { Siliceous limestone with Sponge } \\
\text { spicula }\end{array}$ & Aptian \\
\hline a5 & $43^{\circ} 08,300$ & $05^{\circ} 31,000$ & 220 & Marls & Aptian \\
\hline a6 & $43^{\circ} 08,000$ & $05^{\circ} 31,000$ & 200 & Marls & Aptian \\
\hline v1 & $43^{\circ} 08,600$ & $05^{\circ} 29,500$ & 180 & & Valanginian \\
\hline d1 & $43^{\circ} 08,74$ & $05^{\circ} 32,78$ & 5 & Dolostone & Upper Jurassic? \\
\hline d2 & $43^{\circ} 07,08$ & $05^{\circ} 31,150$ & 160 & Dolostone & Upper Jurassic? \\
\hline d3 & $43^{\circ} 05,150$ & $05^{\circ} 31,000$ & $150-300$ & Dolostone & Upper Jurassic? \\
\hline d4 & $43^{\circ} 04,150$ & $05^{\circ} 25,300$ & 200 & Dolostone & Upper Jurassic? \\
\hline $\mathrm{m} 1$ & $43^{\circ} 04,300$ & $05^{\circ} 39,850$ & 110 & Phyllade & Paleozoic \\
\hline $\mathrm{m} 2$ & $43^{\circ} 02,000$ & $05^{\circ} 42,850$ & $150-200$ & Phyllade & Paleozoic \\
\hline $\mathrm{m} 3$ & $43^{\circ} 01,600$ & $05^{\circ} 44,300$ & $150-200$ & Phyllade & Paleozoic \\
\hline $\mathrm{m} 4$ & $43^{\circ} 03,600$ & $05^{\circ} 33,150$ & & Phyllade & Paleozoic \\
\hline
\end{tabular}




\section{ACCEPTED MANUSCRIPT}

\begin{tabular}{|c|c|c|c|c|c|} 
m5 & $43^{\circ} 04,150$ & $05^{\circ} 30,000$ & $150-350$ & $\begin{array}{c}\text { Conglomerate with metamorphic } \\
\text { pebbles }\end{array}$ & Pliocene \\
\hline p1 & $43^{\circ} 05,250$ & $05^{\circ} 27,000$ & 200 & & Permian \\
\hline
\end{tabular}



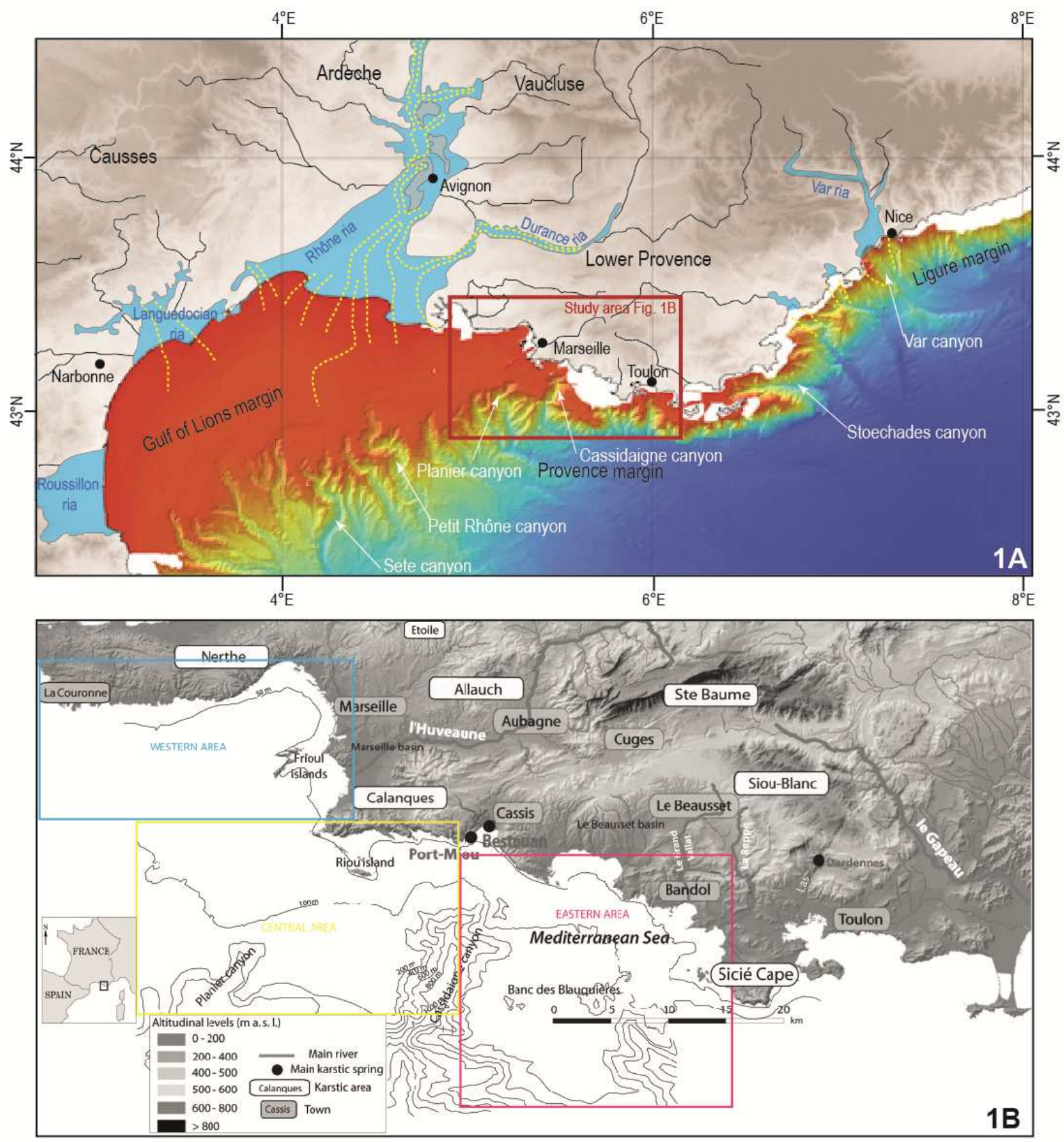


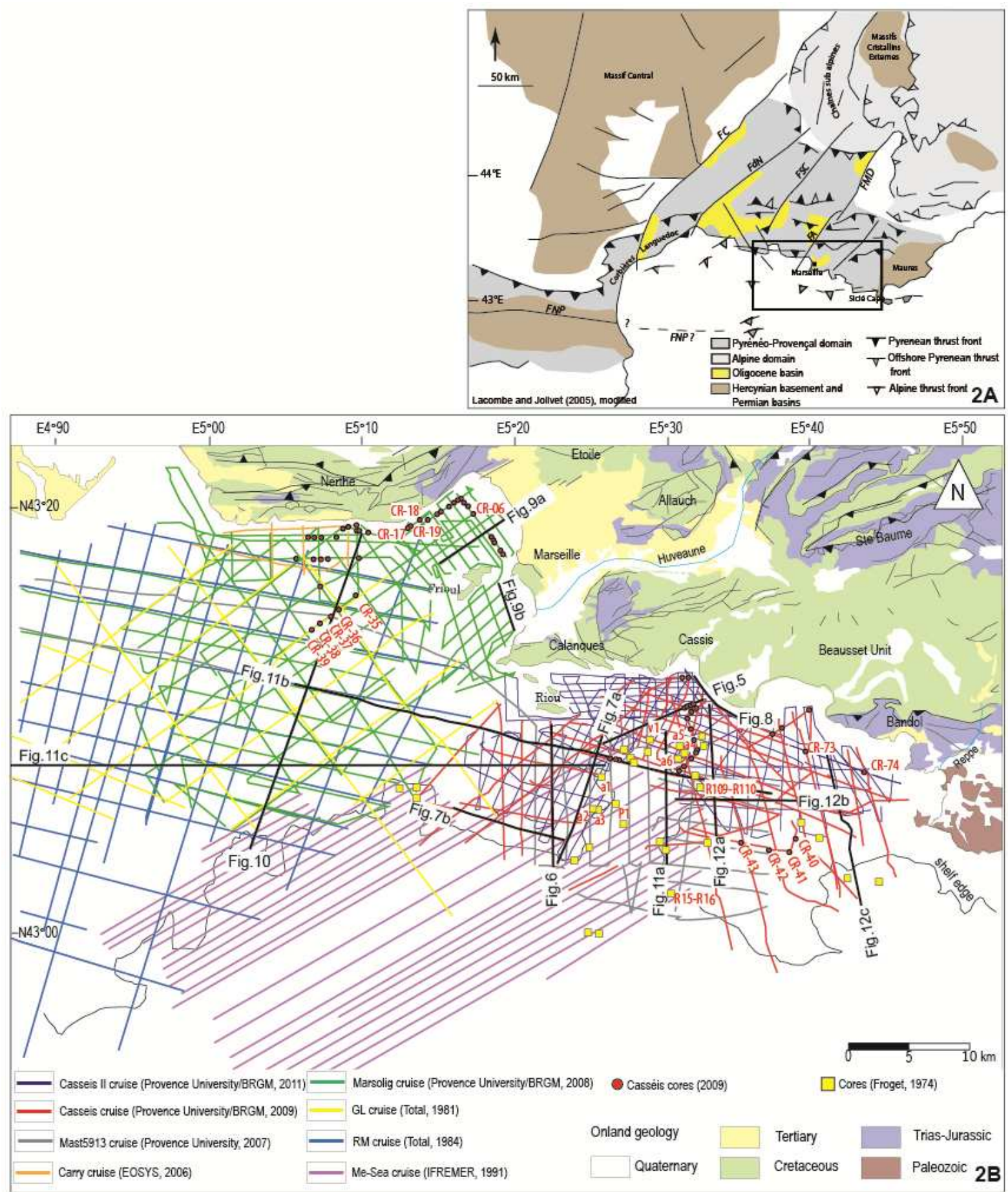



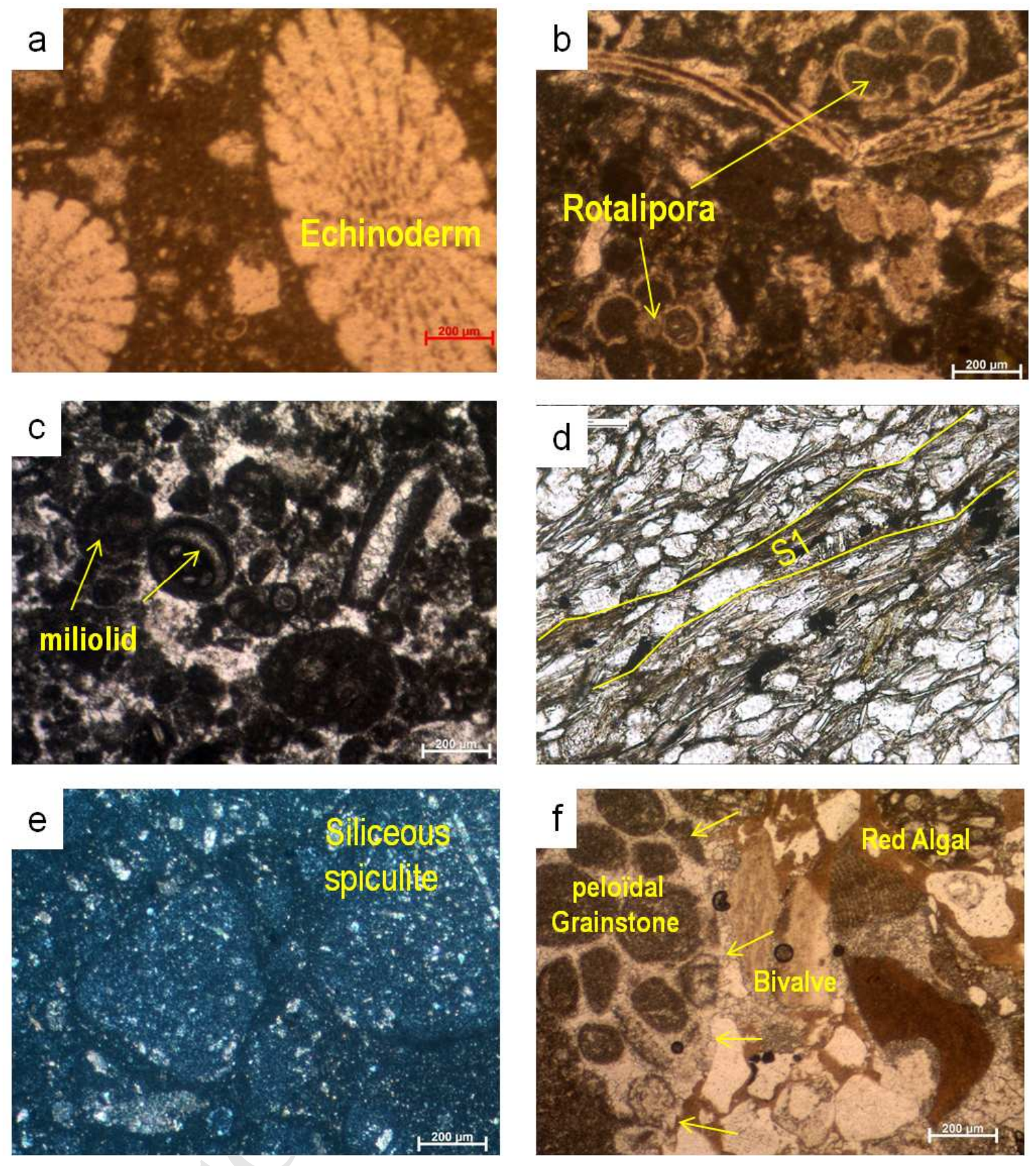
ACCEPTED MANUSCRIPT

\begin{tabular}{|c|c|c|c|c|c|c|}
\hline $\begin{array}{l}\text { Sismo- } \\
\text { strati- } \\
\text { graphic }\end{array}$ & $\begin{array}{c}\text { Reflection } \\
\text { configuration }\end{array}$ & $\begin{array}{l}\text { Reflection } \\
\text { continuity }\end{array}$ & $\begin{array}{l}\text { Reflection } \\
\text { amplitude } \\
\text { and frequency }\end{array}$ & $\begin{array}{l}\text { Bounding } \\
\text { relationship }\end{array}$ & Age interpretation & Example \\
\hline Unit & $\begin{array}{l}\text { Parallel to } \\
\text { sigmoidal }\end{array}$ & Continuous & $\begin{array}{l}\text { HR and LR: } \\
\text { Low amplitude } \\
\text { low frequency } \\
\text { VHR: High amplitude }\end{array}$ & $\begin{array}{l}\text { Draping the underlying } \\
\text { topography. } \\
\text { Onlaps at the base, } \\
\text { topped by sea-bottom }\end{array}$ & Plio-quaternary & HR \\
\hline Unit $6 b$ & Semiparallel & $\begin{array}{l}\text { Continuous to } \\
\text { semicontinuous }\end{array}$ & $\begin{array}{l}\text { High amplitude } \\
\text { low frequency }\end{array}$ & $\begin{array}{l}\text { Filling paleo- } \\
\text { topography. } \\
\text { Limited at the top } \\
\text { by } \cup 6\end{array}$ & $\begin{array}{l}\text { Oligocene (Hypothesis 1) or } \\
\text { Pliocene (Hypothesis 2) }\end{array}$ & 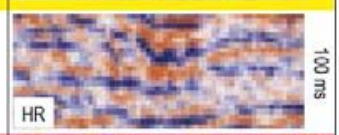 \\
\hline Unit 5 & Semiparallel & Semicontinuous & $\begin{array}{l}\text { Variable amplitude } \\
\text { high frequency }\end{array}$ & $\begin{array}{l}\text { Onlaps above the } \\
\text { underlying unit. } \\
\text { Thinning out towards } \\
\text { the coast. } \\
\text { Troncations at the top. }\end{array}$ & $\begin{array}{l}\text { Miocene } \\
\text { (post-rift: } \\
\text { Burdigalian to Tortonian) }\end{array}$ & 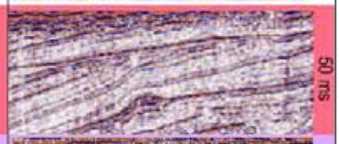 \\
\hline Unit 4 & Semiparallel & Semicontinuous & $\begin{array}{l}\text { Variable amplitude } \\
\text { high frequency }\end{array}$ & $\begin{array}{l}\text { Faulted and folded unit } \\
\text { filling paleo-topography } \\
\text { structured in half grabens }\end{array}$ & $\begin{array}{l}\text { Oligo-Miocene } \\
\text { (syn-rift: } \\
\text { Chattian to Burdigalian) }\end{array}$ & $x_{0}=\frac{8}{3}$ \\
\hline Unit 3 & Oblique & Semicontinuous & $\begin{array}{l}\text { High amplitude, } \\
\text { very high frequency }\end{array}$ & $\begin{array}{l}\text { Laterally limited } \\
\text { by oblique or vertical } \\
\text { surfaces. Top truncated by } \\
\text { flat angular unconformity } \\
\text { or drapped by Unit } 4\end{array}$ & $\begin{array}{l}\text { Oligocene } \\
\text { (Rupelian) }\end{array}$ & sing \\
\hline Unit 2 & Semiparallel & Semicontinuous & $\begin{array}{l}\text { Variable amplitude } \\
\text { high frequency }\end{array}$ & $\begin{array}{l}\text { Limited at the base by U1 } \\
\text { Top truncated by a flat } \\
\text { angular unconformity }\end{array}$ & Cenomanian to Coniacian & 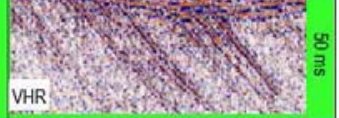 \\
\hline Unit 1 & Semiparallel & Continuous & $\begin{array}{l}\text { High amplitude, } \\
\text { high frequency }\end{array}$ & $\begin{array}{l}\text { Restricted in the central } \\
\text { area syncline. } \\
\text { Top truncated by flat } \\
\text { angular unconformity }\end{array}$ & Aptian & \\
\hline Unit 0 & $\begin{array}{l}\text { Oblique (UOa) or } \\
\text { chaotic (UOb) }\end{array}$ & Discontinuous & $\begin{array}{l}\text { HR: Low amplitude } \\
\text { VHR: Variable amplitude } \\
\text { high frequency }\end{array}$ & $\begin{array}{l}\text { Top truncated by flat } \\
\text { angular unconformity } \\
\text { Laterally bounded by } \\
\text { fauits }\end{array}$ & $\begin{array}{l}\text { UOa: Berriasian to Hauterivian } \\
\text { UOb: Upper Hauterivian to } \\
\text { Barremian }\end{array}$ & HR \\
\hline $\begin{array}{c}\text { Basement } \\
\text { Unit Us }\end{array}$ & Chaotic & Discontinuous & Low amplitude & $\begin{array}{l}\text { Top limited by an } \\
\text { unconformity }\end{array}$ & $\begin{array}{c}\text { Paleozoic and } \\
\text { Mesozoic (pre-Cretaceous) }\end{array}$ & (1) \\
\hline
\end{tabular}




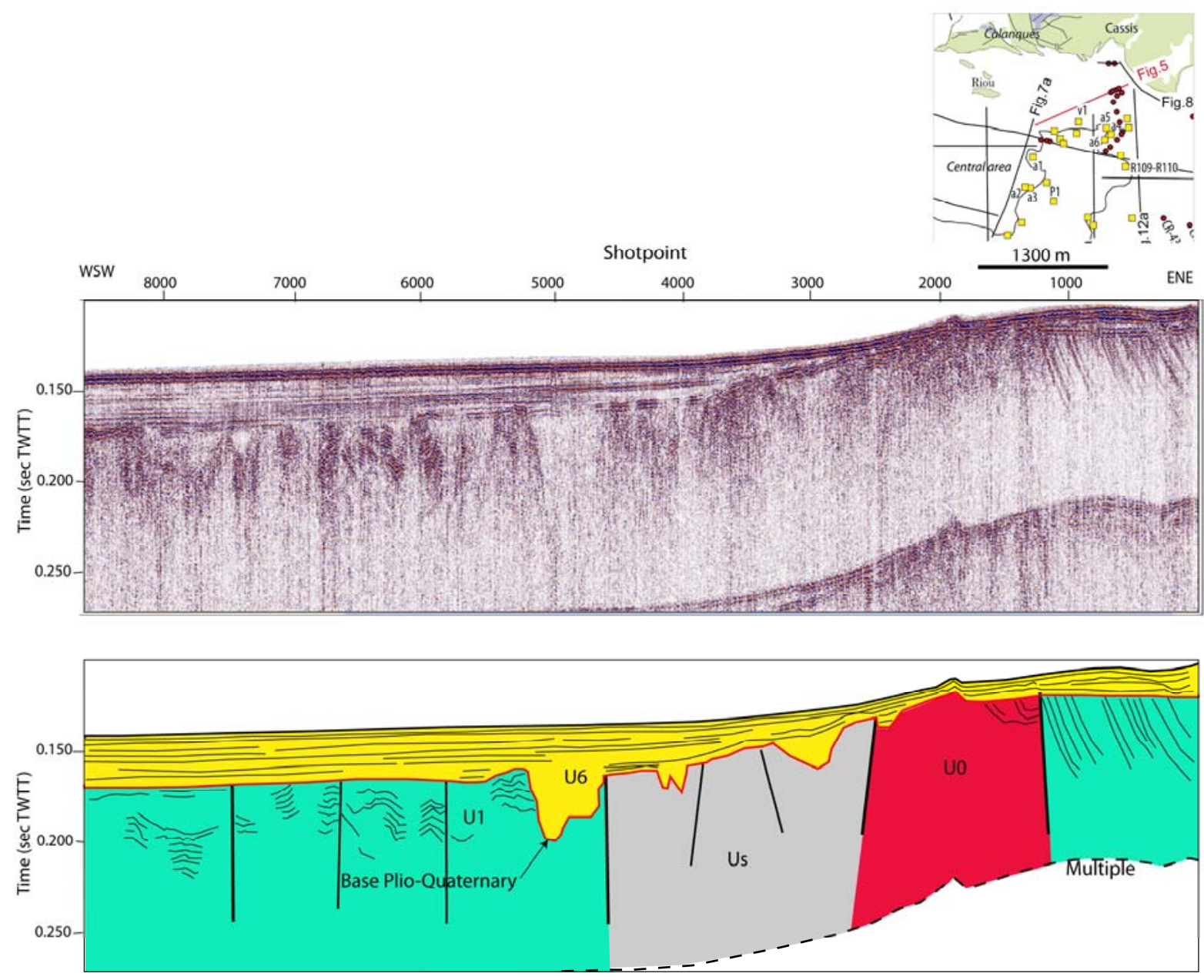



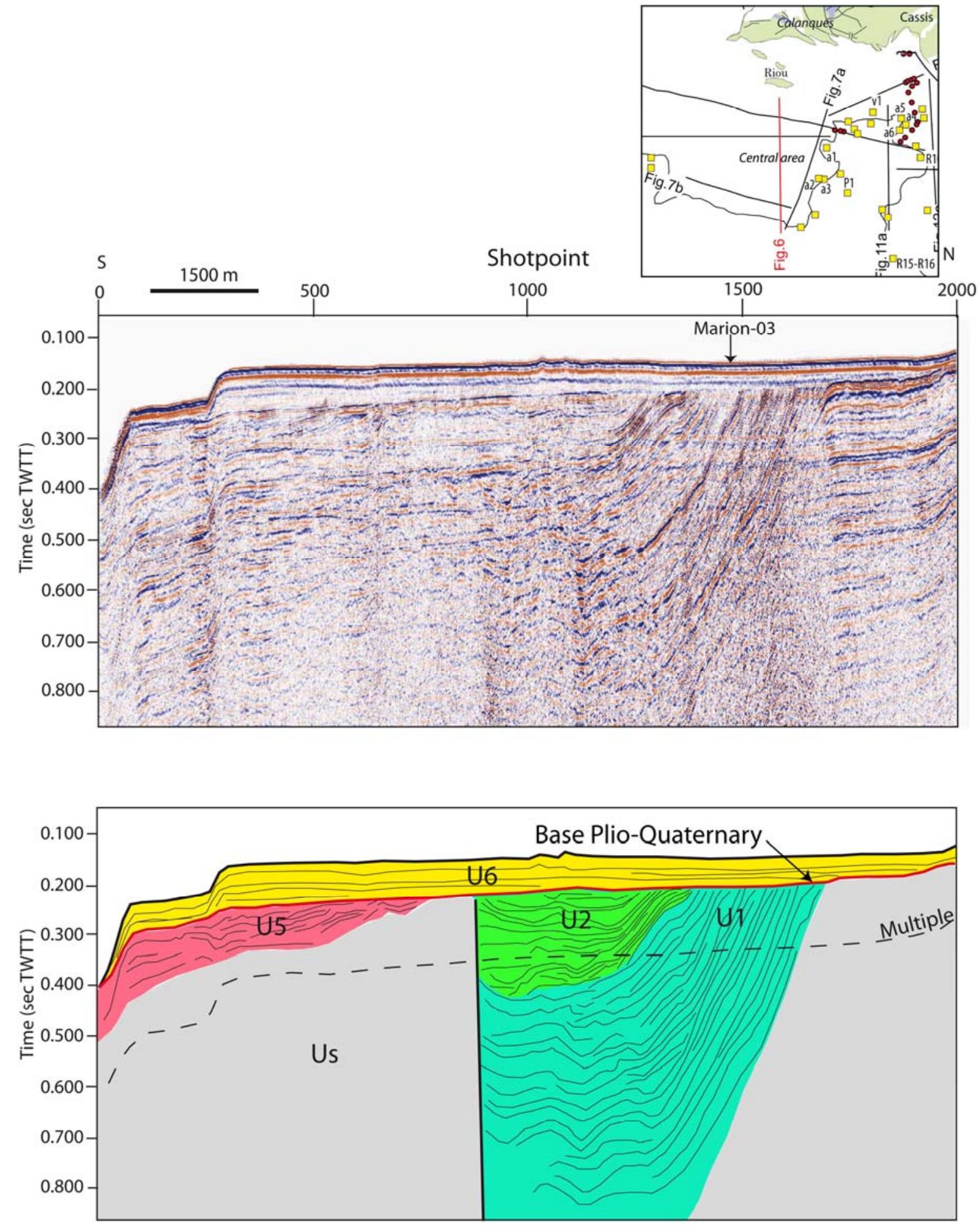


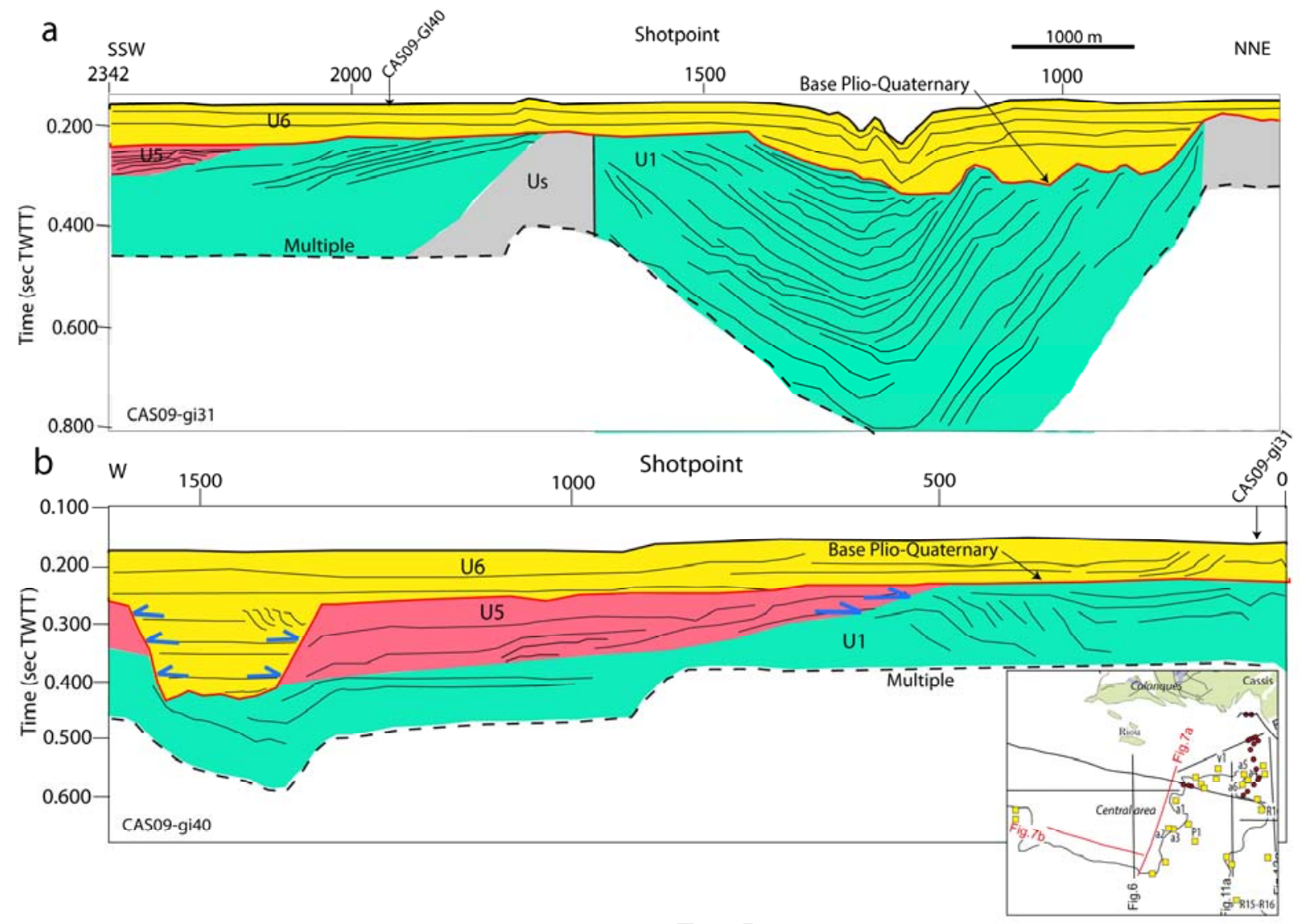



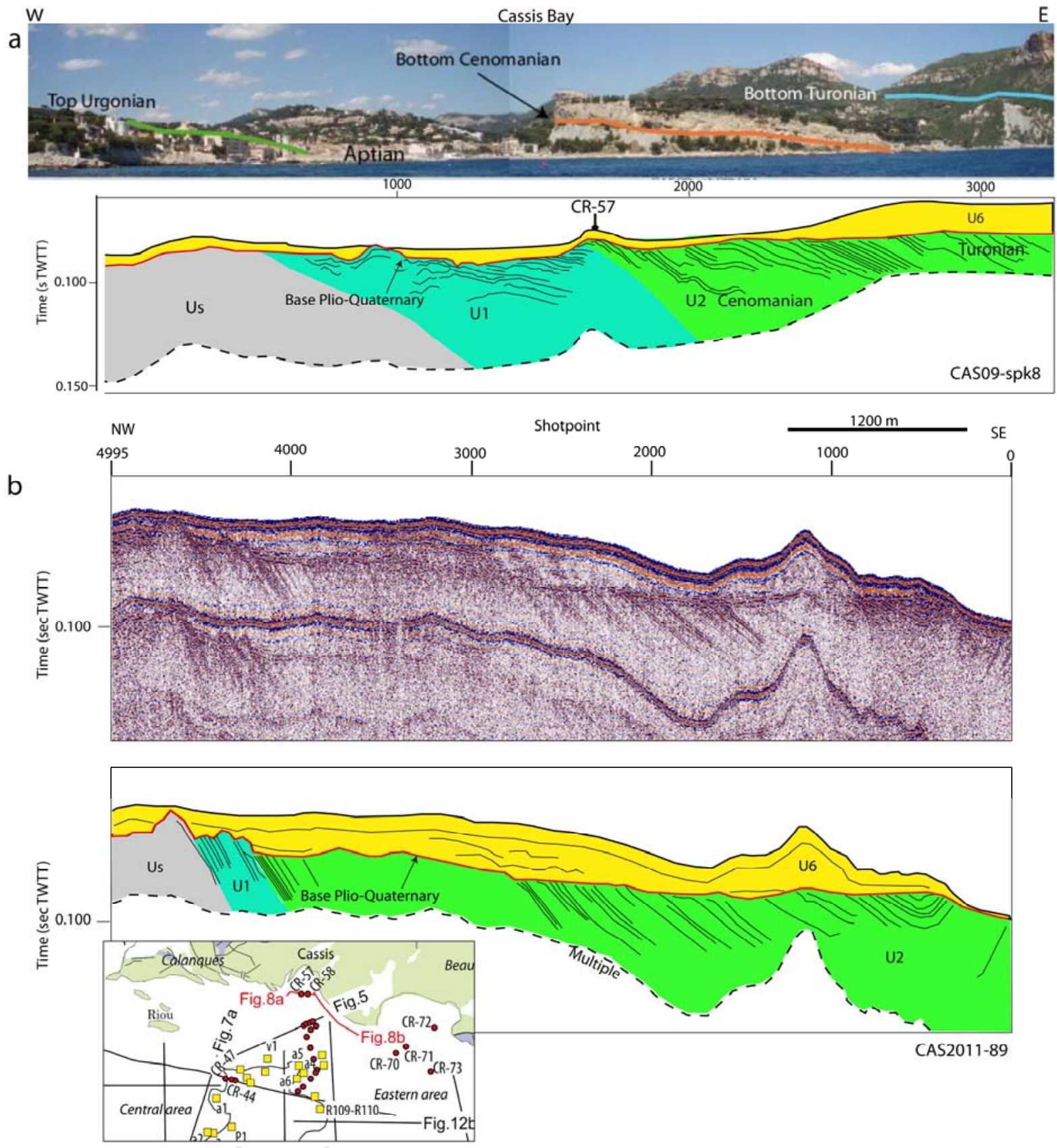


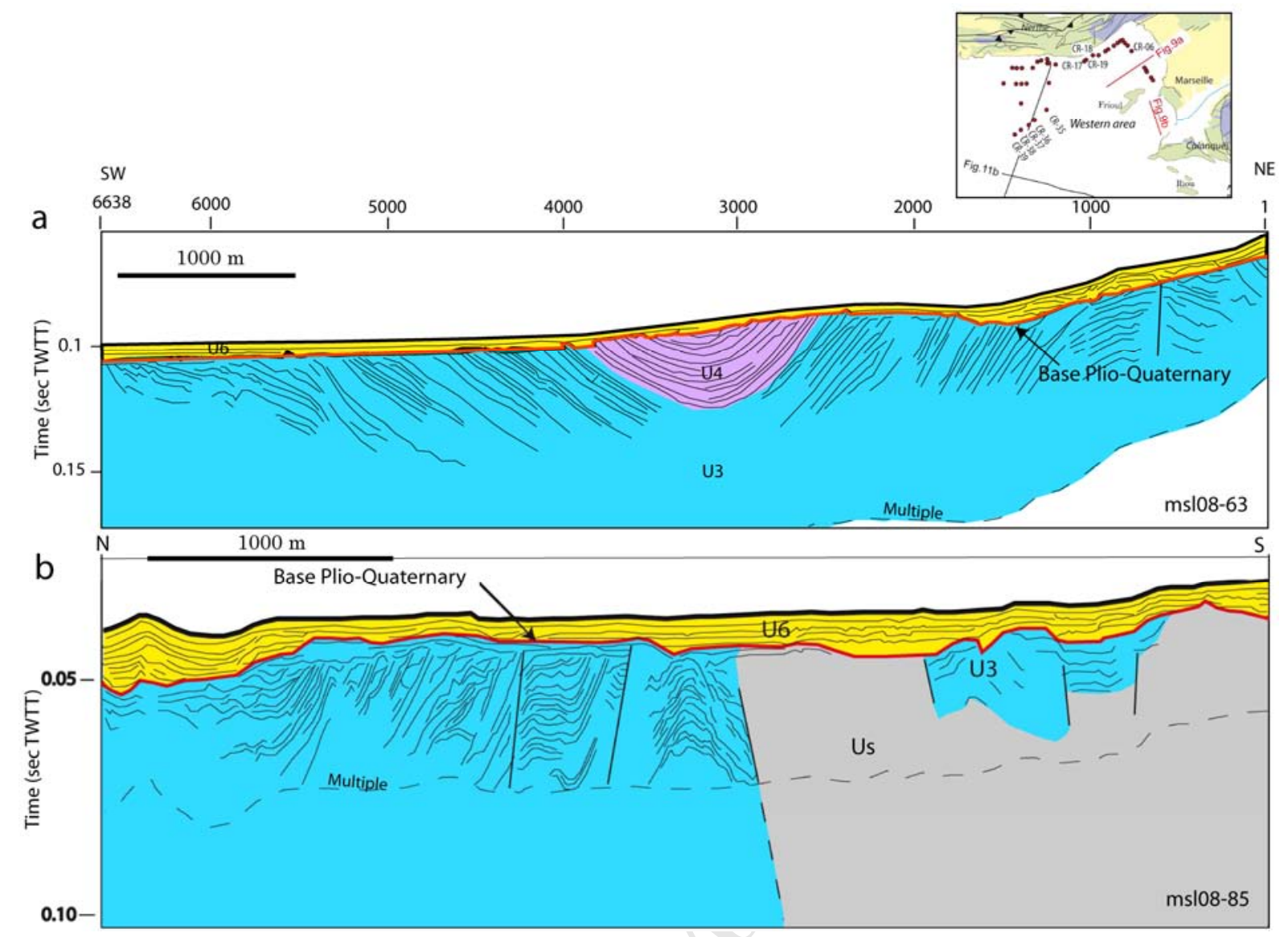




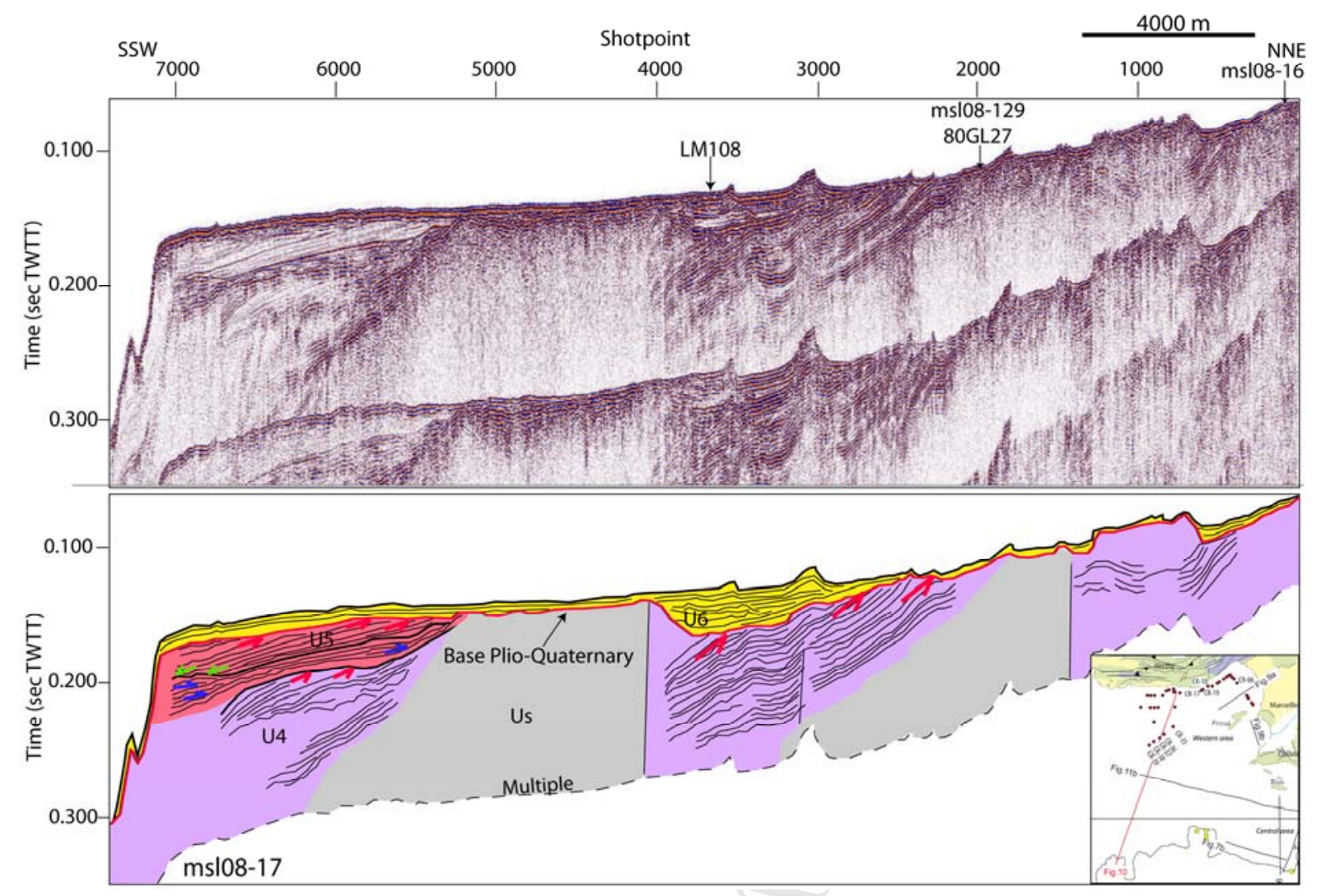




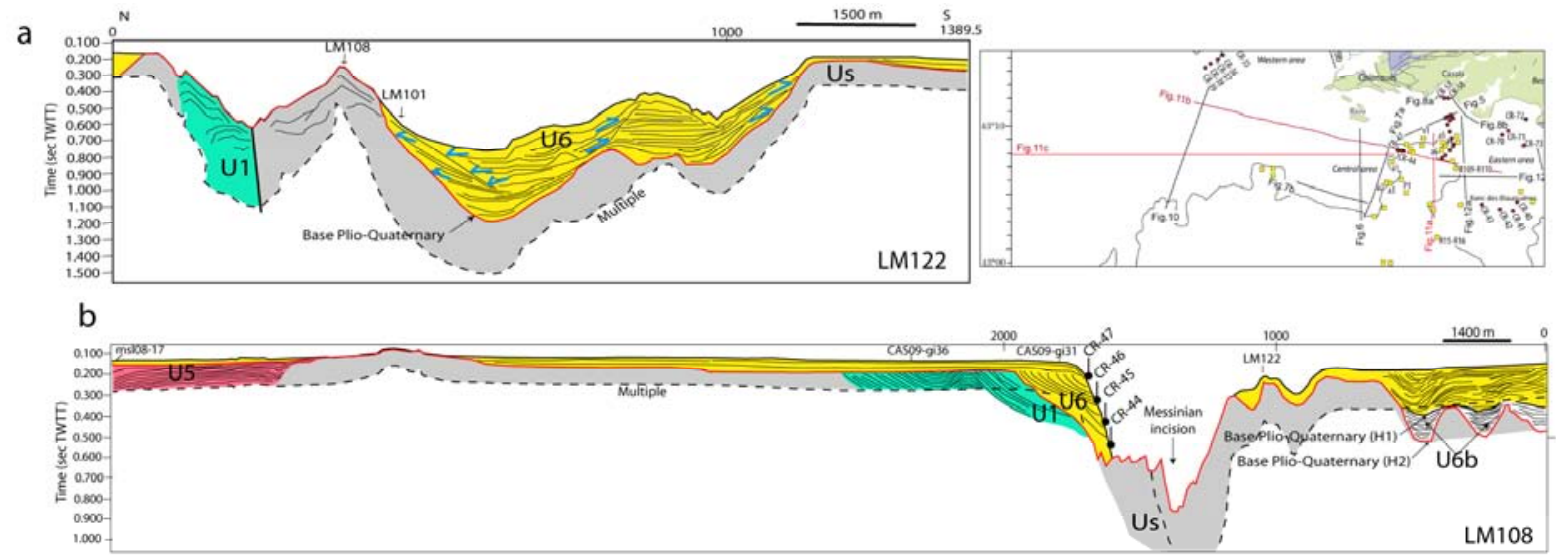

C

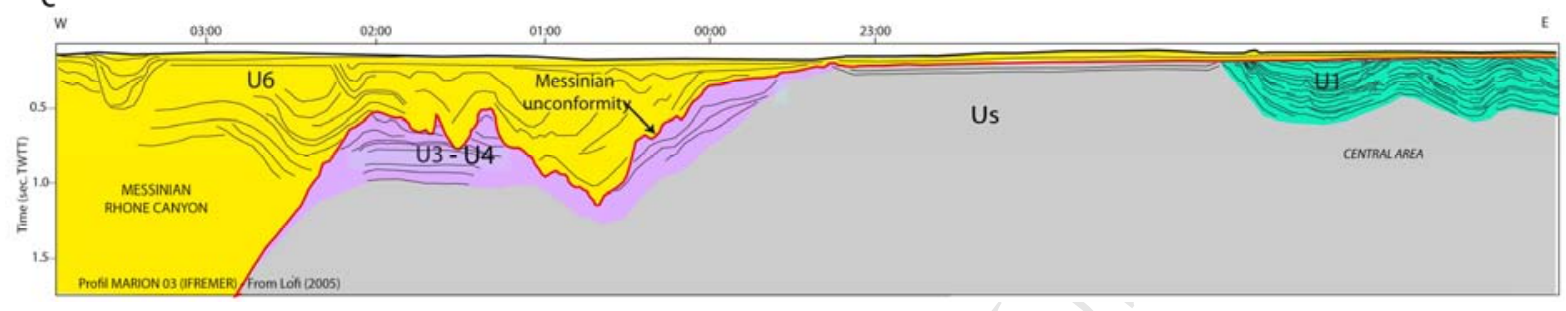




\section{ACCEPTED MANUSCRIPT}

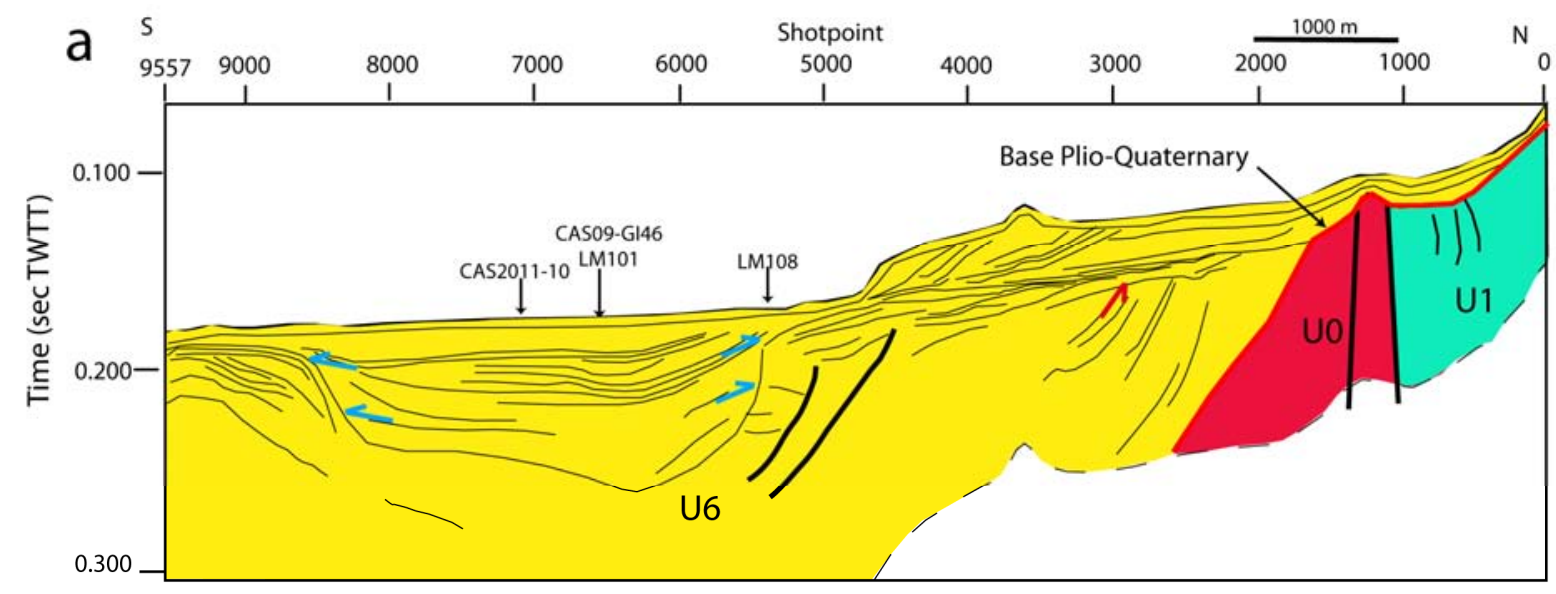

b
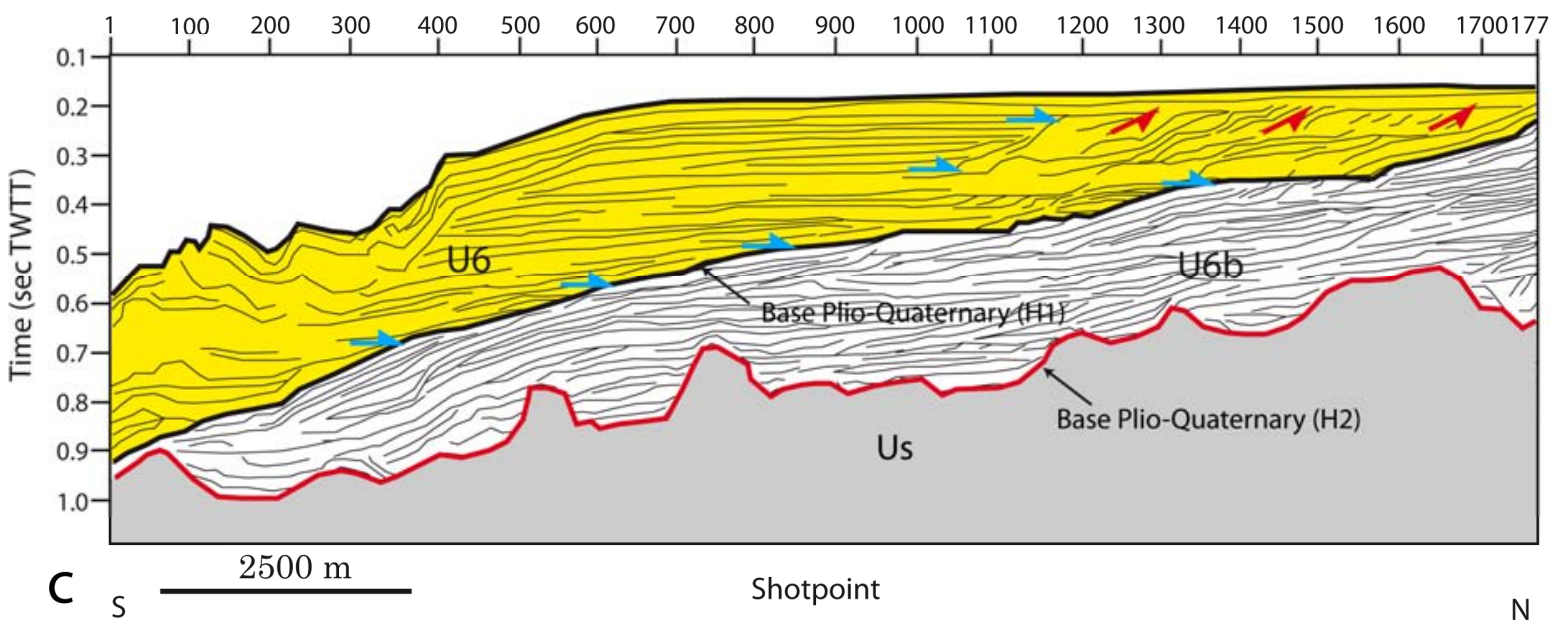

Shotpoint

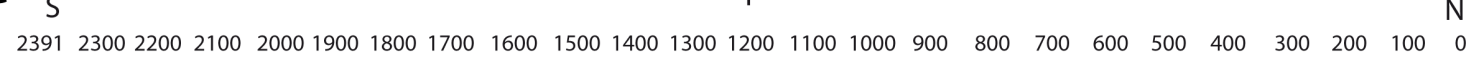

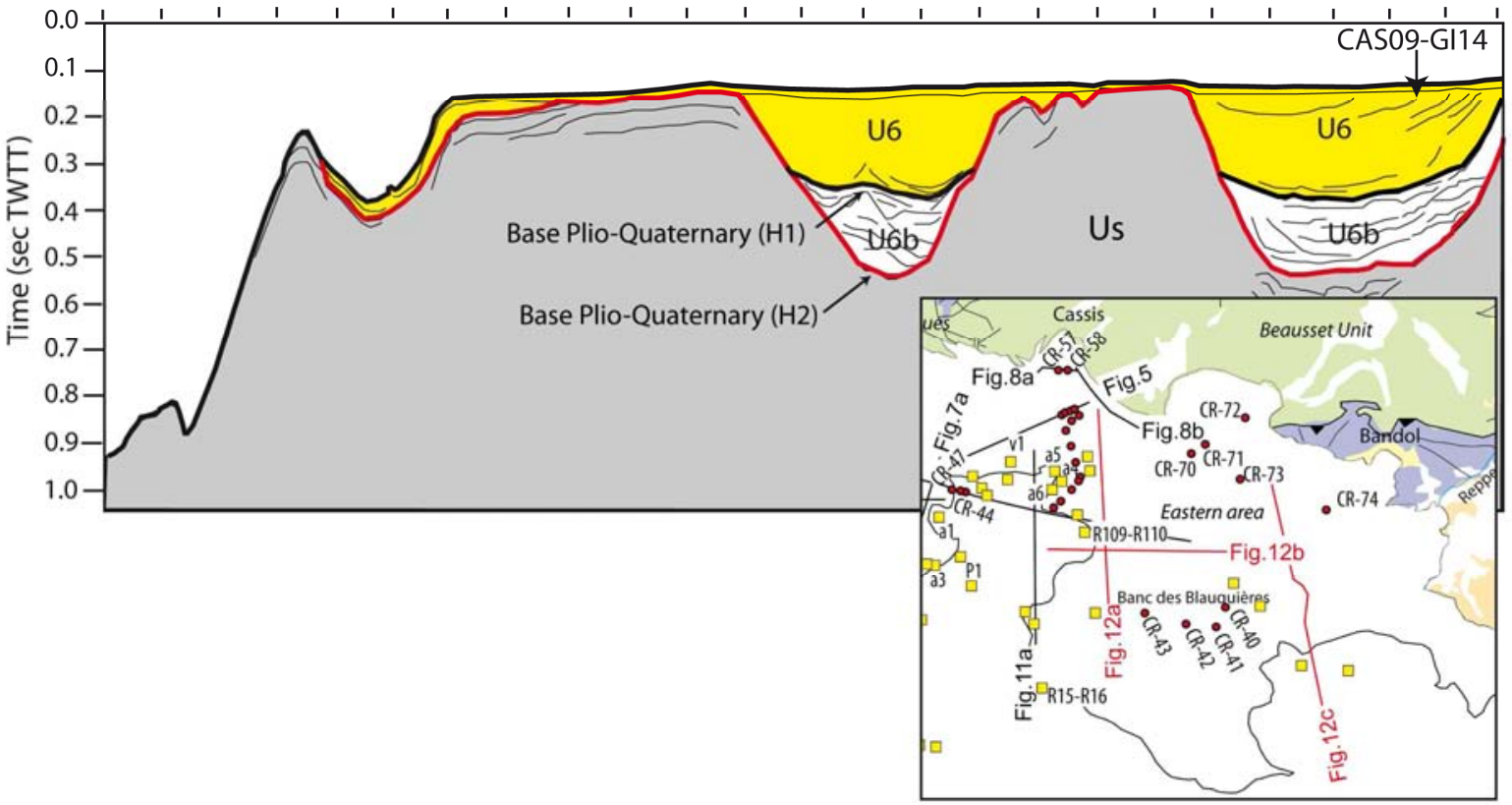




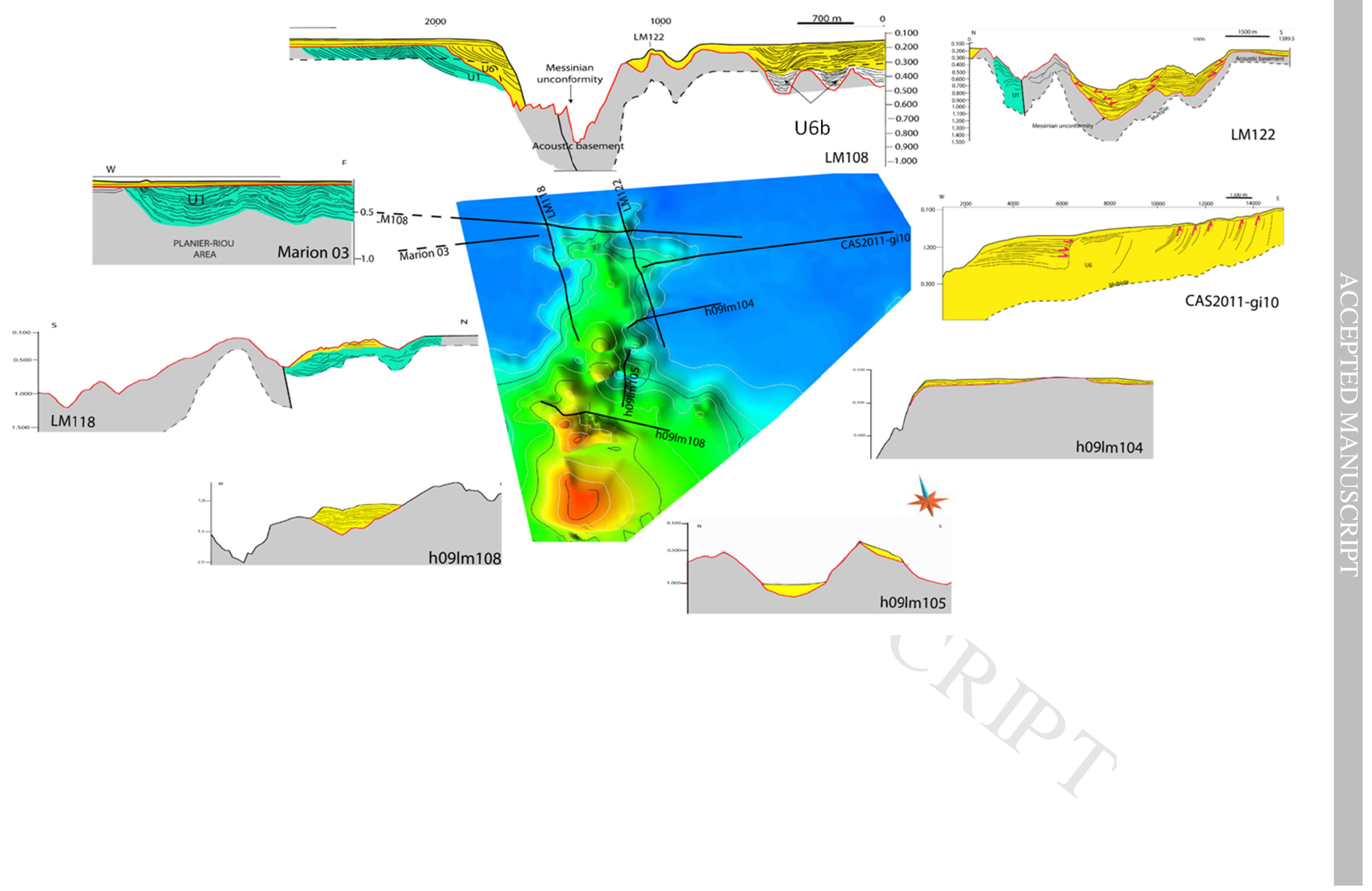




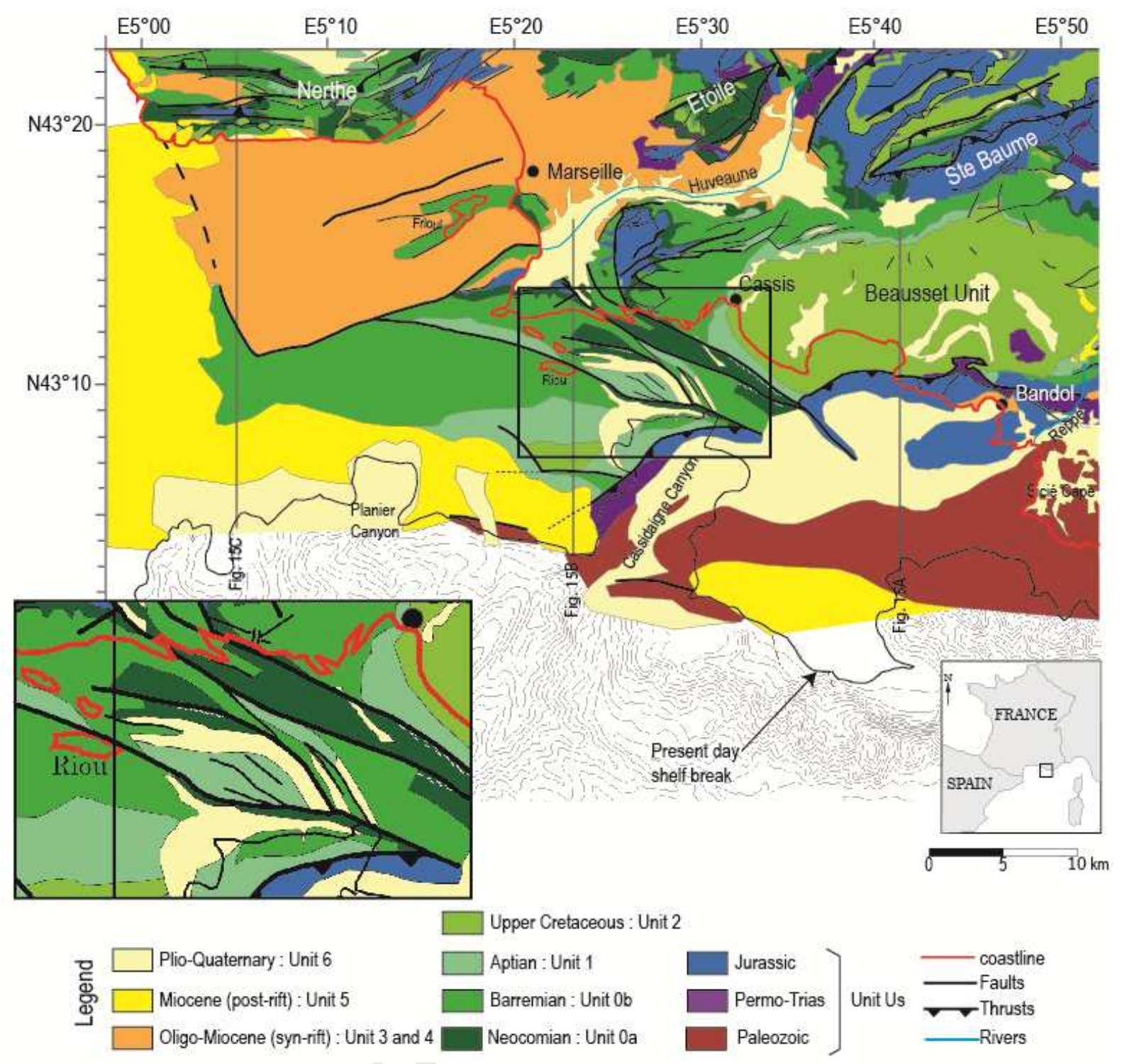




\section{ACCEPTED MANUSCRIPT}

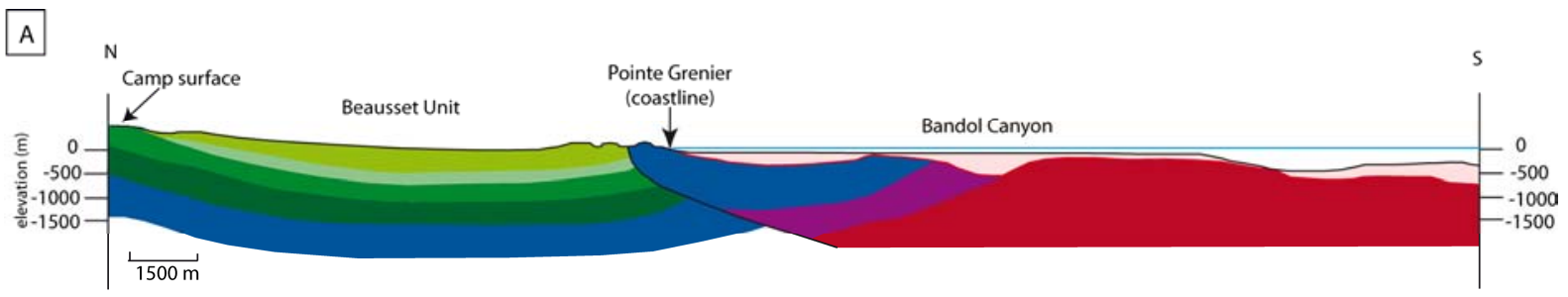

$B \quad \mathrm{~N}$ Cirque des Walkyries

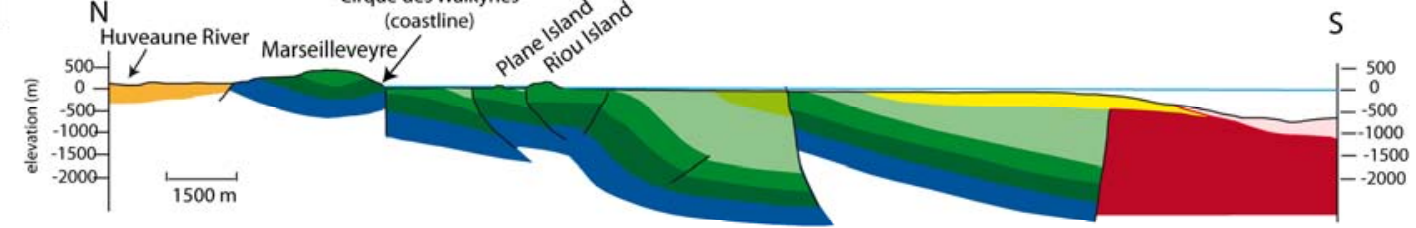

C

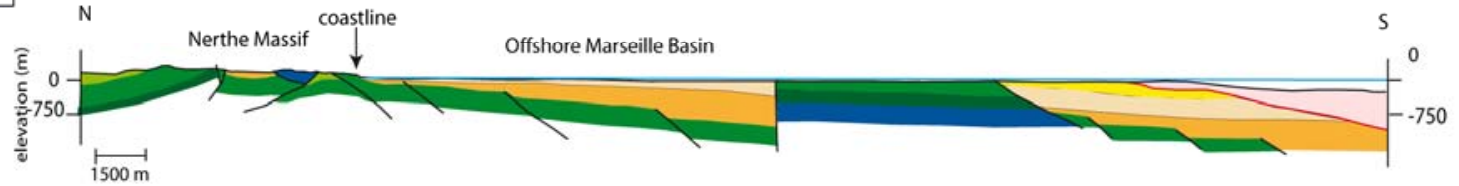

\begin{tabular}{|c|c|c|c|}
\hline Plio-Quaternary & Oligocène & Barremian & Carbonifer-Permo-Trias \\
\hline Miocène (post-rift) & Cénomanian-Turonian & Berriasian-Hauterivian & Metamorphic Paléozoïc \\
\hline Miocène (syn-rift) & Aptian & Jurassic & $\begin{array}{l}\text { niveau marin } \\
\text { topographie-bathymétrie } \\
\text { Base Plio-Quaternaire }\end{array}$ \\
\hline
\end{tabular}




\section{ACCEPTED MANUSCRIPT}

A
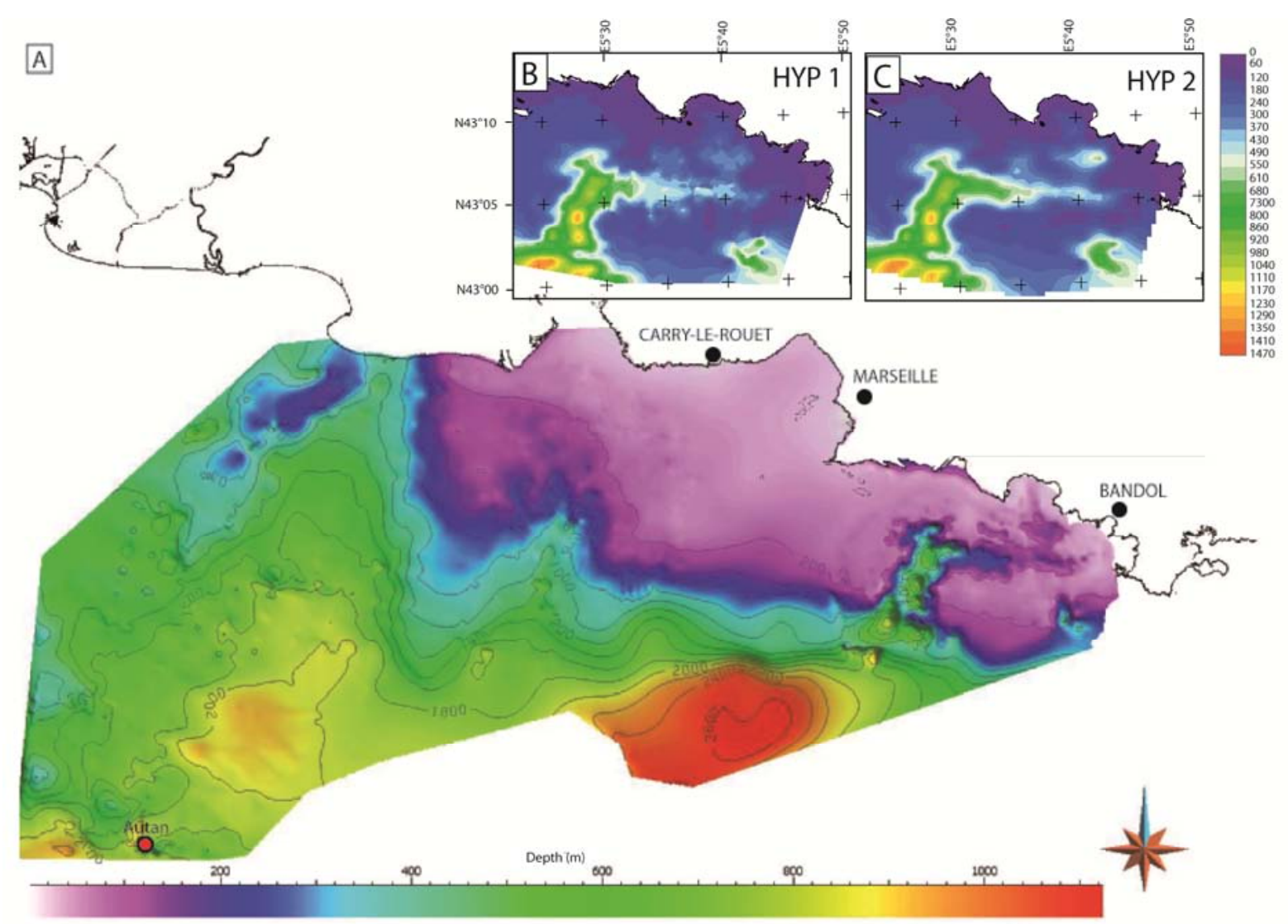

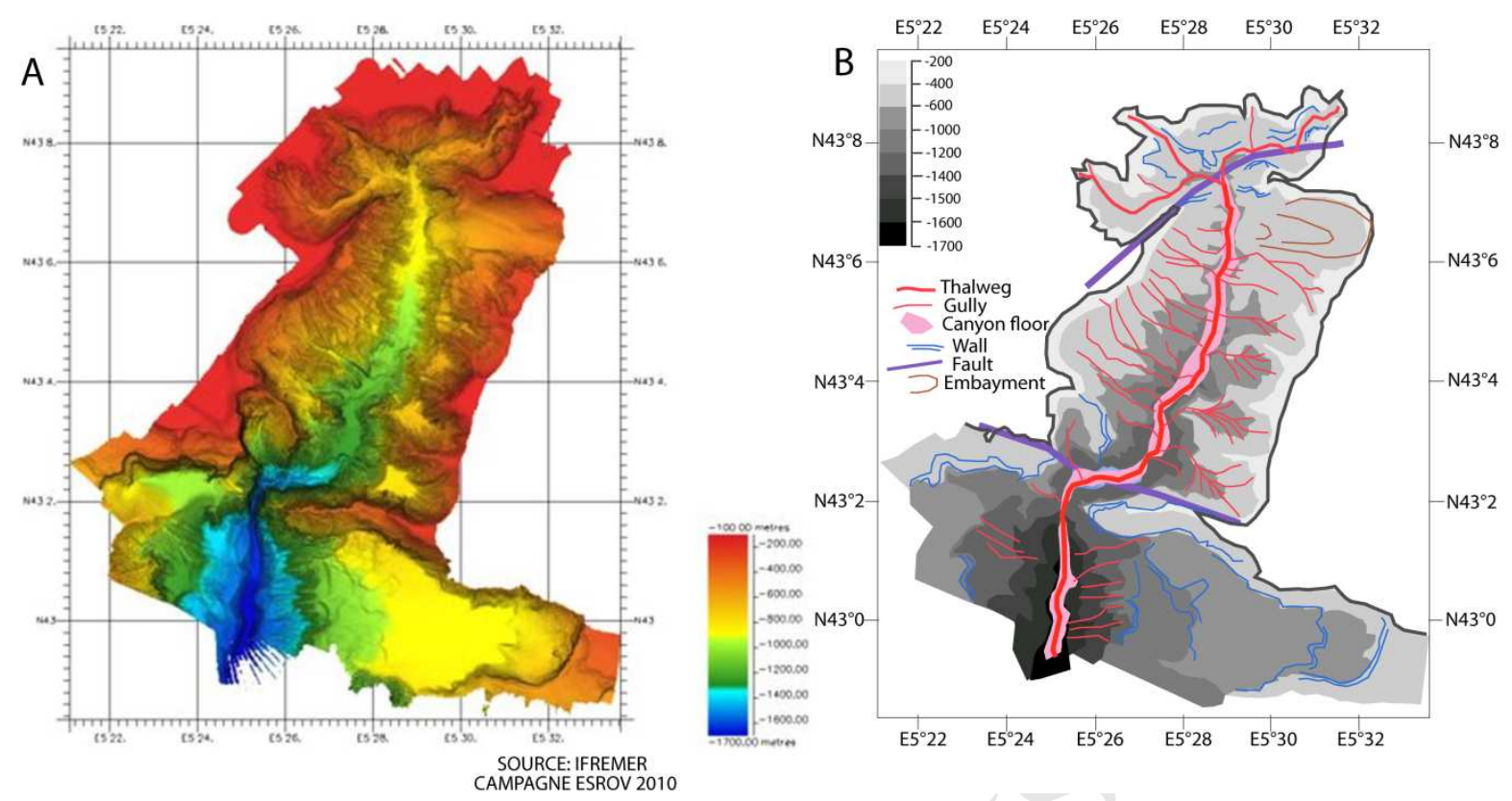

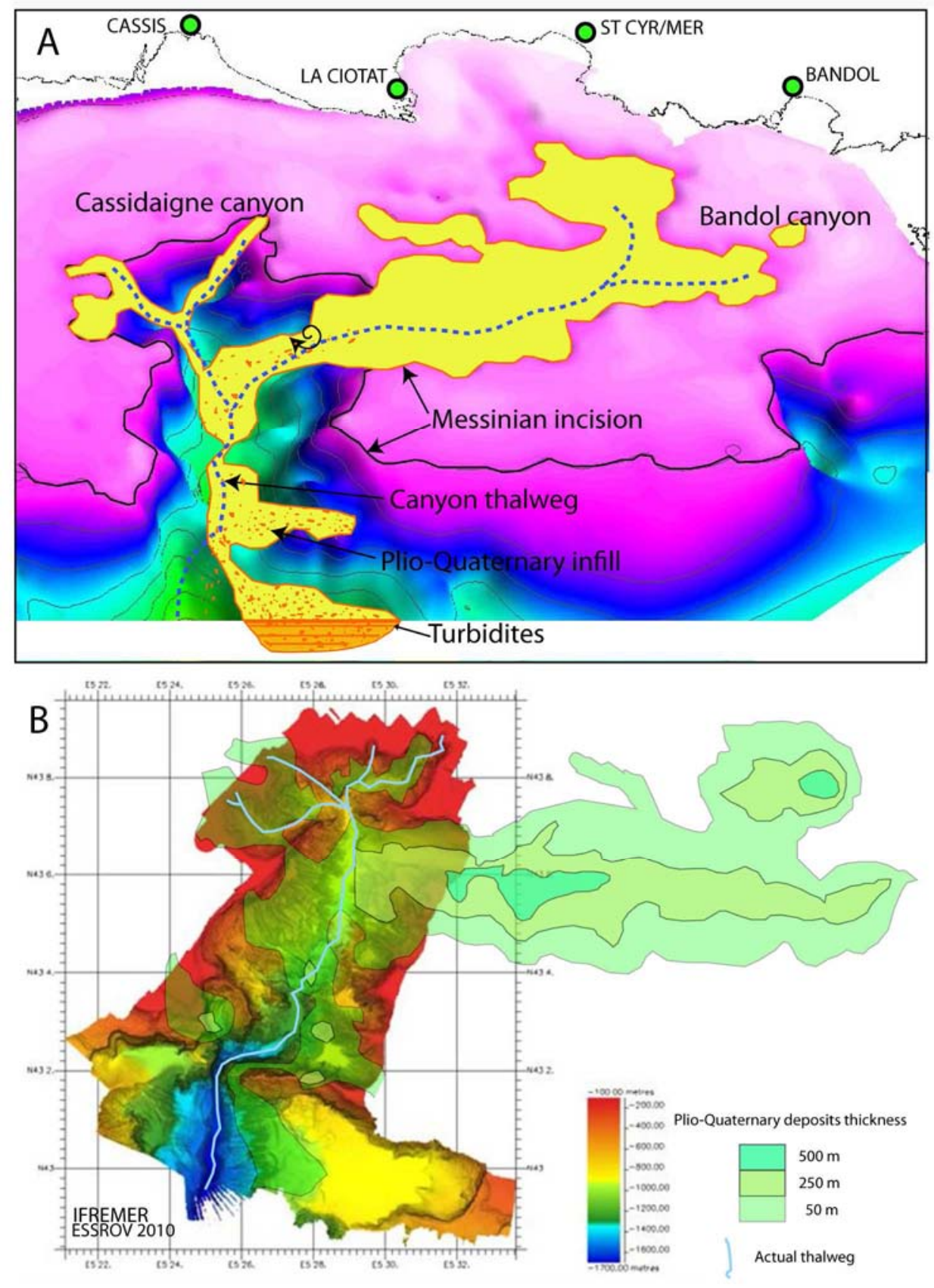


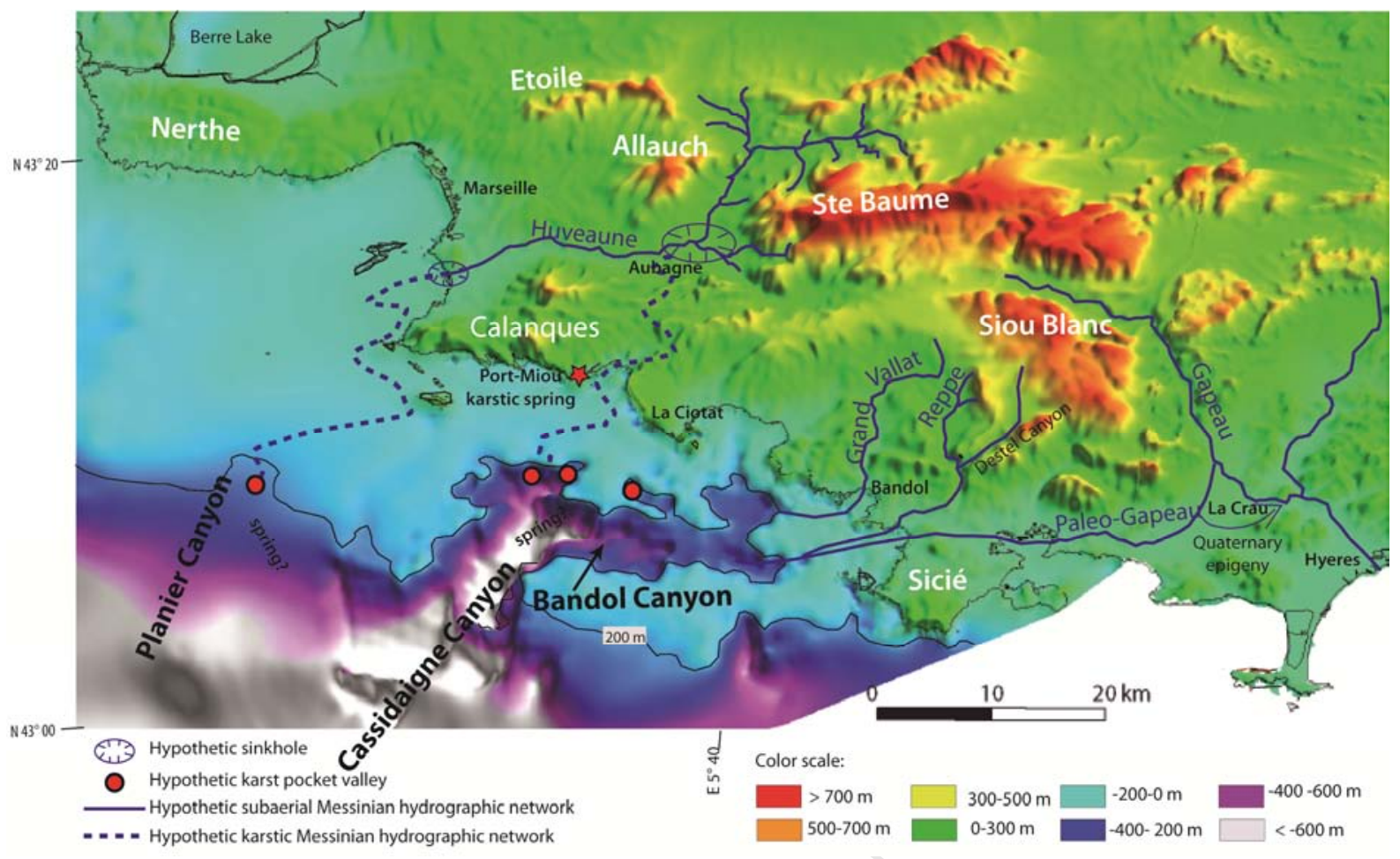

